\title{
Efficacy and Safety of Divaza for The Correction of Oxidative Disturbances in Patients with Cerebral Atherosclerosis: A Randomized Controlled Trial
}

\section{Victoria V. Fateeva ( $\sim$ v.v.fateeva@mail.ru )}

First Moscow State Medical University of the Ministry of Health of the Russian Federation (Sechenov University)

Nataliia U. Lashch

Pirogov Russian National Research Medical University

Pavel R. Kamchatnov

Pirogov Russian National Research Medical University

Tatiana N. Fedorova

Research Center of Neurology

Olga A. Muzychuk

Research Center of Neurology

Kristina K. Khacheva

Research Center of Neurology

Nataliya V. Pizova

Yaroslavl State Medical University

Alexander U. Malygin

Yaroslavl, Russian Federation

Olga A. Shavlovskaya

First Moscow State Medical University of the Ministry of Health of the Russian Federation (Sechenov University)

Kseniya V. Nikulina

First Moscow State Medical University of the Ministry of Health of the Russian Federation (Sechenov University)

Albert V. Abrosimov

Regional Clinic Hospital

Yulia A. Gerasimova

Regional Clinic Hospital

Konstantin S. Glushkov

Korolev, Russian Federation

Anna V. Lebedeva

Pirogov Russian National Research Medical University

\section{Research article}

Keywords: cerebral atherosclerosis, oxidative stress, antioxidant effect, Divaza, placebo-controlled study

Posted Date: October 12th, 2020

DOl: https://doi.org/10.21203/rs.3.rs-63542/v1

License: (c) (i) This work is licensed under a Creative Commons Attribution 4.0 International License. Read Full License 


\section{Abstract}

Objective: To determine if Divaza was safe and effective for the correction of oxidative disturbances and to stabilize cognitive impairment in patients with cerebral atherosclerosis.

Study design: 12-week multicenter, randomized, double-blind, placebo-controlled, prospective trial in parallel groups.

Setting: 10 clinical centers across the Russian Federation.

Interventions: Patients were randomized into two groups and instructed to take either 2 tablets of the study drug or placebo 3 times per day in conjunction with basic therapy.

Outcomes: The primary outcome was a change in the average endogenous antioxidant potential after the completion of the study. The laboratory indicators of oxidative stress were analyzed at baseline and then after 12 weeks of therapy using iron-induced chemiluminescence analysis. The Montreal cognitive assessment test was used as a secondary outcome measure to evaluate cognitive impairment at the end of the study.

Results: 124 outpatients with a mean age of $60.7 \pm 7.6$ years were enrolled and randomly assigned to receive Divaza ( $n=65)$ or placebo ( $n=59)$. The Administration of Divaza restored the activity of the endogenous antioxidant system. The change in the average level of lipoprotein resistance to oxidation after 12 weeks of therapy, compared to the baseline, was significantly higher in the Divaza group (14.8 \pm 14.7 [14.8 \pm 14.7 ] seconds latent period versus $6.4 \pm 16.9[6.9 \pm 16.7]$ seconds in the placebo group $(p=0.007$ [ $=0.0107])$. In addition, a recovery of cognitive impairment was observed in all patients of the Divaza group at the end of treatment; this was significantly better when compared with the placebo group (100 [100] \% versus 89.5 [89.1] \%, respectively, $p=0.0272[p=0.0128])$. The treatment was safe, well-tolerated, and had a high compliance rate.

Conclusions: Divaza is a safe and effective therapeutic option for attenuating oxidative stress and recovery of cognitive impairment in patients with cerebral atherosclerosis.

Trial registration: clinicaltrials.gov NCT03485495, of April 02, 2018.

\section{Article Summary \\ Strengths and limitations of this study:}

- The study is the largest multicenter clinical trial to evaluate the safety and efficacy of the drug Divaza for the correction of oxidative disturbances in patients with cerebral atherosclerosis.

- In the study, the drug was used in addition to basic therapies, which included antihypertensive drugs, antiplatelet agents, anticoagulants, statins, and drugs for the treatment of diabetes mellitus. Thus, it was not possible to evaluate the effectiveness of monotherapy with the drug Divaza in the correction of oxidative disorders in patients with cerebral atherosclerosis.

\section{Background}

Cerebrovascular diseases (CVD) have become an increasingly important healthcare problem. Extended life expectancy has resulted in an increased number of elderly people, most of whom have signs of cerebral microangiopathy [1, 2]. According to the World Health Organization (WHO), the number of elderly and seniors in the Russian Federation will increase from 14 to 19 million by 2020, and will reach 40 million by 2050 [3].

Impaired delivery of oxygen and glucose through the vessels altered by atherosclerosis is the basis of ischemic brain damage [4]. The lack of energy substrates causes disruption of the function of Adenosine Triphosphate (ATP)-dependent neuronal ion pumps [5]. This leads to the suppression of nerve impulse generation, and an accompanying decrease in the effectiveness of communication between neurons [6, 7].

The key mechanism underlying ischemic brain damage is oxidative stress (OS) caused by an excess of free radicals [8 - 10]. Normally, free radical formation is limited by the activity of the antioxidant system, which includes both enzymatic and non-enzymatic mechanisms [11, 12]. The exhaustion of the antioxidant system is facilitated by ischemia, comorbid somatic diseases, old and senile age, unbalanced diet, and smoking [11, 13].

Elevated levels of free radicals target lipid structures of cell membranes, primarily, those of neurons, the damage of which leads to the disturbance of cell structure and function $[2,14]$. Also, free radicals damage endothelial cells, resulting in the development of endothelial dysfunction; this manifests itself as impaired vasodilation and decreased ability to control tissue blood flow $[15,16]$.

Such pathological reactions result in the disruption of autoregulation of cerebral blood flow, exacerbation of cerebral ischemia and structural changes in the brain [12, 17 - 20]. Loss of synapses, reduction of dendrite number, and complete or partial destruction of the myelin sheath of white matter develop progressively. These processes lead to subsequent brain tissue death, accompanied by the appearance and progression of neurological deficit [17 - 20]. OS is considered as a cause of cognitive impairment in patients with cerebral atherosclerosis.

Page 2/25 
Cognitive impairment is considered to be the target symptom of therapeutic measures. Treatment of patients with cognitive impairment should be individually focused on pathogenic factors. It should include antioxidant medications that improve systemic circulation and cerebral blood flow and optimize neural metabolism. Divaza is a combination of the technologically processed, highly diluted affinity-purified antibodies to the brain-specific protein S-100 and endothelial NO synthase (eNOS). It has a wide range of neurotrophic effects that include antioxidant, neuroprotective, anxiolytic, antidepressant, and antiamnesic [21]. The action of the first component, technologically processed, highly diluted affinity-purified antibodies to the brain-specific S-100 protein (TP Abs to S-100), has a modifying effect on the functional activity of the brain-specific S-100 protein; this process connects information flow and metabolic processes in the brain. Experimental and clinical studies have shown that the anxiolytic effect of affinitypurified antibodies to the brain-specific S-100 is not accompanied by sedative or myorelaxant action. The second component, technologically processed, highly diluted affinity-purified antibodies to eNOS (TP Abs to eNOS), enhances eNOS enzymatic activity and increases the production of nitric oxide (NO); this has a positive effect on the functional state of the vascular endothelium [21, 22].

Simultaneous administration of TP Abs to S-100 and TP Abs to eNOS has a positive effect on cerebral hemodynamics, neuroprotective, and antioxidant effects [21].

In this paper, we present the results of a recent clinical study aimed to evaluate the safety and efficacy of Divaza for the correction of oxidative disturbances in patients with cerebral atherosclerosis.

\section{Methods Trial design}

This was a 12-week multi-center, randomized, double-blind, placebo-controlled, prospective trial in parallel groups conducted at 10 clinical centers in the Russian Federation. It was performed to evaluate the efficacy and safety of Divaza. All patients signed an informed consent form before enrollment. The study was registered at clinicaltrials.gov (NCT03485495) [23]. The study complies with CONSORT guidelines. Partition ratio 1:1.

\section{Participants}

The study included 124 outpatient patients with established cerebral atherosclerosis, with cognitive impairment (Montreal Cognitive Assessment $(\mathrm{MoCA})<26)$, and without significant impairment of competence (Modified Rankin Scale $(\mathrm{mRS}) \leq 1)$. Cerebral atherosclerosis in patients manifested itself in the form of asthenia, noise in the head, vertigo, headache. Cognitive impairment in patients manifested itself in the form of decreased memory, concentration, mental performance and difficulty in remembering new information.

\section{Inclusion and exclusion criteria}

Inclusion criteria for the study were: outpatients of both sexes 40 - 75 years old, diagnosed with cerebral atherosclerosis, established by the presence of all listed features listed below:

- arterial hypertension and focal neurological symptoms in combination with general cerebral symptoms (headache, vertigo, head noise, memory impairment, and asthenia);

- ultrasound signs of atherosclerotic plaques in carotid arteries;

- $\mathrm{CT} / \mathrm{MRI}$ features of cerebral small vessel disease (Computed Tomography / Magnetic Resonance Imaging 1,0 - 1,5 T).

Patients included in the study were cognitively impaired, with continuous therapy aimed at reducing the risk factors for atherosclerosis. One month before the start of the study patients were required to use contraception.

Exclusion criteria were: acute or exacerbated chronic inflammatory disease, including acute respiratory disease, the symptoms of which persist for more than 7 days, changes in dose and / or combination of therapy aimed at reducing the risk factors for atherosclerosis, use of not allowed drugs, and pregnancy.

During the study, the presence and nature of adverse events (AEs), their intensity (severity), association with drug administration, and outcome were recorded, and vital signs were evaluated.

Also, patients received basic therapy aimed at treating the underlying disease and secondary prevention of stroke and other vascular events, including antihypertensive drugs [angiotensin converting enzyme inhibitors, angiotensin II receptor antagonists, $\alpha$ - and $\beta$-blockers, calcium antagonists, and diuretics (thiazide, antagonists aldosterone receptors)], antiplatelet agents (acetylsalicylic acid, clopidogrel, dipyridamole, and ticlopidine), anticoagulants, statins, and hypoglycemic agents.

\section{Randomization and blinding}

After completing all assessments at baseline, patients were randomized into two groups using an automated interactive voice system based on a random number generator in a 1:1 ratio. Patients of the first group took the drug Divaza 2 tablets 3 times a day for 12 weeks; patients of the second 
group took placebo according to the same regimen. In order to maintain confidentiality, each patient was assigned a personal code that did not change during the study.

In this study, double blind placebo control was used. Tablets of the drug Divaza (lot K020218) and placebo (lot K010218) had the same appearance and organoleptic properties. Placebo tablets (000 «NPF «MATERIA MEDICA HOLDING») contained lactose monohydrate $0.267 \mathrm{~g}$, microcrystalline cellulose $0.03 \mathrm{~g}$, magnesium stearate $0.003 \mathrm{~g}$ but no active substances - TP Abs to S-100 and TP Abs to eNOS.

The test drug was delivered in boxes and packages which lacked any labels indicating the presence of active substances. Patients, researchers, research center staff, and the project sponsor team were not informed about the prescribed study therapy (Divaza or placebo) until the trial was completed and the database was closed.

\section{Intervention and fidelity monitoring}

During the screening visit (1st Visit, from - 5 to 0 days), doctors collected the medical history and complaints and performed a physical examination. Cognitive impairment was assessed by MoCA, and the level of functional competence by mRS.

On the 2nd Visit (Day 0) patients who met all the inclusion criteria and none of the exclusion criteria were randomly assigned to one of two groups: patients in Group 1 received the drug Divaza and patients in Group 2 received placebo.

The first dose of Divaza or placebo was administered at the 2nd Visit at the clinical center under the doctor's supervision. Before the first dose patient's blood was collected for the evaluation of the serum oxidant/antioxidant balance. The monitoring and treatment of the patients continued for 12 weeks, during which three more visits occurred.

During the 3rd Visit (week 4), the doctor collected complaints, performed the physical examination, and assessed the severity of cognitive impairment (MoCA). The doctor monitored the prescribed, basic, and related therapy, and assessed the safety of the treatment. To assess safety, (1) indicators of vital signs of study participants were recorded; (2) the presence and nature of AEs during the period of therapy, their relationship with taking the drug, and other characteristics were noted.

During the 4th Visit (week 8), the doctor made a telephone call to the patient and assessed the safety of the treatment.

During the final 5th Visit (week 12), the doctor evaluated the severity of cognitive impairment (MoCA). Also, patient blood was collected for the evaluation of the serum oxidant/antioxidant balance.

\section{Sample handling and analysis}

Fasting blood $(10 \mathrm{ml})$ was drawn in the morning in a tube without anticoagulant. To separate the serum, samples were centrifuged at $3000 \mathrm{~g}$ for $15 \mathrm{~min}$ at room temperature. The serum was removed and stored in duplicate at $-80^{\circ} \mathrm{C}$ until sent to the central laboratory. Serum samples were shipped frozen on dry ice. The time for transporting the samples to the central laboratory did not exceed 24 hours. Fe ${ }^{2+}$-induced chemiluminescence (CL) analysis was performed at the Laboratory of Clinical and Experimental Neurochemistry, Research Center of Neurology, 80 Volokolamskoye Shosse, 125367, Moscow, Russian Federation.

Lipid peroxidation (LPO) status and the level of endogenous antioxidant defense were studied on the model of CL of the low density and very lowdensity lipoproteins (LP) [24 - 27]. The total LP fraction was isolated from serum of patients according to the generally accepted method: 2 ml of $0.28 \% \mathrm{CaCl}_{2}$ solution and $0.04 \mathrm{ml}$ of $1 \%$ heparin were added to $0.2 \mathrm{ml}$ of serum, then the tubes were shaken, left for $5 \mathrm{~min}$ at room temperature and then centrifuged at $3000 \mathrm{~g}$ for $15 \mathrm{~min}$ at room temperature. The supernatants were discarded and pellets were resuspended in $0.9 \mathrm{ml}$ of potassium phosphate buffer (60 $\mathrm{mM} \mathrm{KH}_{2} \mathrm{PO}_{4}$ and $\left.105 \mathrm{mM} \mathrm{KCl}, \mathrm{pH} 7.45\right)$ [28].

CL was detected using a Luminometer-1251 (LKB, Sweden). Briefly, a cuvette containing the low density and very low-density serum LP samples was placed in the measuring chamber (heated to $37^{\circ} \mathrm{C}$, with constant stirring) and the background value of $\mathrm{CL}$ was registered. To initiate $\mathrm{CL} 0.1 \mathrm{ml}$ of ferrous sulphate $\left(\mathrm{FeSO}_{4} \cdot 7 \mathrm{H}_{2} \mathrm{O}\right)$ solution was added to the cuvette at a final concentration of $2.5 \mathrm{mM}$, the luminescence curve was recorded and expressed in $\mathrm{mV}$.

The following reaction parameters were analyzed: rapid CL flare amplitude $(\mathrm{mV})$ reflecting the level of preformed LPO products (mainly lipid hydroperoxides); duration of CL latent period (seconds) characterizing LP resistance to oxidation, which reflects the level of endogenous antioxidant potential, and the maximum intensity of chemiluminescence $(\mathrm{mV})$ reflecting LP oxidation capacity [29].

\section{Conditions}

The study was conducted at 10 clinical centers providing outpatient care located in various cities of the Russian Federation, including Vladimir, Moscow, Korolev, and Yaroslavl.

\section{Study duration}

16 months (from April 2018 to August 2019). 


\section{Primary end point}

A changing in the mean endogenous antioxidant potential (LP resistance to LPO) after 12 weeks of therapy compared to baseline was the primary study outcome.

\section{Prespecified secondary end points}

The secondary outcome was the percentage of patients with improved cognitive function ( +1 or more MoCA scores) after 12 weeks of therapy relative to the baseline condition.

Additional outcomes were: changes in the mean level of preformed LPO products (mainly lipid hydroperoxides), after 12 weeks of therapy compared to baseline; changes in the mean level of LP oxidation capacity after 12 weeks of therapy compared to baseline.

The safety of the drug was assessed by the presence and nature of AEs during the treatment period, their severity, connection with the study drug administration, outcome, and dynamics of vital indicators.

\section{Ethical expertise}

The study was conducted with the permission of the Ministry of Health of the Russian Federation № 42 from May 02 , 2018. The study was approved by the Ethics Council at the Ministry of Health of the Russian Federation (protocol № 161 of December 19, 2017) and local ethical committees of medical centers. The randomized clinical trial (RCT) was registered in the international database (ClinicalTrials.gov Identifier: NCT03485495).

The RCT was carried out in accordance with the Rules of Good Clinical Practice (GCP), approved by order of the Ministry of Health of the Russian Federation № 200n from January 04, 2016, international guidelines of GCP, and the Helsinki Declaration of the World Medical Association.

\section{Statistical analysis}

The following rules and assumptions were taken into account when calculating the sample size: the power of statistical criteria was set to $80 \%$ (the probability of not missing an actual effect equaled 0.8 ); the probability of type I error was less than $5 \%$ (the probability of making an erroneous decision about the presence of an effect was less than 0.05 ). There were no preplanned blind interim analyzes. The type I error was divided in equal proportions between the primary and secondary criteria.

Assumptions about the expected effects of an RCT.

Primary end point: the difference in the change in the endogenous antioxidant potential (LP resistance to LPO) between the Divaza and placebo groups will be at least $\varepsilon=20.36$ seconds with a standard deviation of $\sigma=32.1$ seconds [28].

Prespecified secondary end points: the proportion of patients with a decrease in the total score of the MoCA questionnaire by 1 or more points in the Divaza group will be at least $82 \%$, while in the placebo group, the same indicator will be no more than $50 \%$ [29].

Based on these statistical assumptions, the size of each group was 49 participants (sample size for Per Protocol (PP) analysis). Given the possible dropout of at least $20 \%$ of patients during the screening process, as well as during the study for various reasons, it was necessary to obtain a signed informed consent form from at least 124 patients, 62 patients in each group.

Based on the data from two sample sets - Full Analysis Set (FAS) and PP - a performance analysis was carried out: Intention-to-treat (ITT)-analysis and PP-analysis, respectively. The results of the PP-analysis are presented in square brackets.

A safety assessment, including registration of AEs and tolerance of the study therapy, was based on the data of all randomized patients who received at least one dose of the study drug (Safety population).

Data processing was performed using the statistical package SAS-9.4 (Statistical Analysis System, USA). Standard methods of frequency analysis were used (Fisher's exact test); analysis of continuous variables was carried out using the non-parametric Wilcoxon test or Student's t-test, depending on the result of the normality test using the Shapiro-Wilk test; multivariate analysis of continuous and polynomial variables was carried out using analysis of variance for repeated measurements (Repeated Measures ANOVA, PROC MIXED).

\section{Results}

\section{Study participants}

124 patients were assessed for eligibility (Total set). The monitoring revealed that 1 patient was enrolled incorrectly ( $n=1$, Divaza group). This patient's data was excluded from the ITT efficacy analysis. The other patients $(n=123)$ formed a Full analysis set. Based on the results of the treatment of this set ( $n=64$, Divaza group; $n=59$, placebo group) the ITT efficacy analysis was performed. 
The PP-analysis set included 111 patients: 56 in the Divaza group, 55 in the placebo group. Eight patients were excluded from the PP-analysis in the Divaza group due to the inability to continue participating in the trial (inability or refusal of the patient to follow the requirements of the protocol, $\mathrm{n}=4$; patient's desire to prematurely withdraw from the study, $n=3$; the occurrence of AEs requiring to discontinue the study medication (headache), $n=1$ ), 4 patients - in the placebo group (patient's desire to prematurely withdraw from the study, $n=1$; the occurrence of AEs requiring to discontinue the study medication (hypertensive crisis), $n=1$; inability or refusal of the patient to follow the requirements of the protocol, $n=1$; change in dose and / or combination of drugs of basic therapy, $n=1$ ). The results of the PP-analysis are presented in square brackets.

The assessment of therapy safety and tolerability was made based on data from all enrolled patients who received at least one dose of the study drug (Safety population, $n=123$ ). Figure 1 shows a diagram of participant flow through the study.

\section{Patient demographics and baseline characteristics}

The mean age of patients whose data were included in ITT [PP]-analysis in the Divaza group was $61.4 \pm 7.9$ [61.3 \pm 7.8$]$ years, in the placebo group $59.8 \pm 7.4[60.4 \pm 7.1]$ years. There were $21.9 \%$ [23.2\%] male and $78.1 \%$ [76.8\%] female patients in the Divaza group, and $32.2 \%[30.9 \%]$ male and $67.8 \%$ [69.1\%] female patients in the placebo group. There was no significant difference in age $(p=0.16[p=0.40])$ and sex $(p=0.23[p=0.40])$ between the two groups (Table 1).

For quantitative assessment of oxidative stress level in patients with cerebral atherosclerosis the following parameters were determined: the endogenous antioxidant potential, the level of preformed LPO products, and LP oxidation capacity.

Baseline levels of the low density and very low density serum LP resistance to oxidation in the Divaza and placebo groups were reduced: $42.4 \pm 13.1$ [40.8 \pm 10.8 ] seconds and 42.9 \pm 11.2 [42.2 \pm 10.9 ] seconds, respectively, compared with the values taken as the conditional norm of $54-95$ seconds [28]. This finding indicates a decrease in the endogenous antioxidant potential in patients with cerebral atherosclerosis (Table 2).

In addition to the evaluation of the antioxidant system, the oxidant potential of all patients was assessed by determining the levels of preformed LPO products, and LP oxidation capacity.

Baseline level of the preformed LPO products (mainly lipid hydroperoxides), in the Divaza group was $72.5 \pm 14.1$ [70.7 \pm 13.5$] \mathrm{mV}$, in the placebo group $72.8 \pm 12.9$ [72.7 \pm 12.3$] \mathrm{mV}$ (Table 3 ) with the value adopted as the conditional norm $57-65 \mathrm{mV}$ [28]. Elevated baseline levels of lipid hydroperoxides in patients with chronic cerebral blood circulation deficiency indicate an intensification of LPO processes.

The Baseline levels of LP oxidation capacity in the Divaza group were 1027.3 \pm 204.7 [1021.3 \pm 207.6$] \mathrm{mV}$, in the placebo group $-993.8 \pm 264.1$ [973.8 \pm 259.7$] \mathrm{mV}$, with values accepted as the conditional norm 937-983 mV [28]. High levels of baseline capacity of the low density and very low density serum LP to oxidation indicate the increase of activity of LPO processes (Table 4).

The evaluation of the baseline levels of parameters of oxidative stress in patients with cerebral atherosclerosis demonstrates an imbalance between the oxidant and antioxidant systems with the activation of LPO processes and the depletion of antioxidant potential.

\section{Comorbidities and concomitant therapy}

93.8\% [96.4\%] of the Divaza group and 93.2\% [96.4\%] of the placebo group patients had various comorbidities ( $p=1.000$ [p=1.000]). 23.3\% [22.2\%] of the Divaza group and $23.6 \%$ [20.8\%] of the placebo group patients had one concomitant disease, most of the patients from both groups had two or more concomitant conditions (Table 5).

Patients received basic therapy for cardiovascular diseases (arterial hypertension, coronary heart disease, and chronic heart failure), diabetes mellitus, etc. No differences were found between the groups in terms of frequency of use of concomitant therapy medications. There was no significant difference between the groups in the number of patients with concomitant diseases $(p=1.000[p=1.000])($ Table 6).

\section{Reproductive function and contraception rates in patients}

All male and female reproductive age patients used contraception during the study. The results of the pregnancy tests were negative in all female reproductive participants.

\section{Patient compliance}

Counting the doses of medication returned at the end of the study showed a high level of patient compliance with the prescribed therapy. Compliance on the Visit 3 in the Divaza group was 100.1 \pm 6.5 [100.2 \pm 5.4 ], in the placebo group $-99.8 \pm 5.6$ [100 \pm 5.6$]$, on the Visit $5-99 \pm 10.4$ [100.2 \pm 5.45$]$ and $98.2 \pm 11.3[99.6 \pm 5.1]$ respectively. There was no significant difference in compliance between the groups ( $G$ roup $* V i s i t »: F_{1 / 67.8}=0.04 ; p=0.83$ [«Group*Visit»: $\left.\left.F_{1 / 111}=0.05 ; p=0.82\right]\right)$.

\section{Efficacy assessment}

\section{Study end points}




\section{Primary end point}

By the end of 12 weeks of treatment, an increase in the average level the low density and very low density serum LP resistance to LPO was observed in the Divaza group from $42.4 \pm 13.1$ [ $40.8 \pm 10.8]$ seconds to $55.6 \pm 12.5$ [55.6 \pm 12.5$]$ seconds, in the placebo group - from $42.9 \pm 11.2[42.2 \pm 10.9]$ seconds to $49.4 \pm 14.3[49.3 \pm 14.4]$ seconds.

The change in the average level of the low density and very low density serum LP resistance to oxidation in the Divaza group was significantly higher than in the placebo group after 12 weeks of therapy (14.8 \pm 14.7 [ $14.8 \pm 14.7$ ] seconds compared to $6.4 \pm 16.9$ [6.9 \pm 16.7$]$, respectively). The difference in changes of the average levels of the low density and very low density serum LP resistance to oxidation between the two groups was $8.4 \pm 15.9$ [7.9 \pm 15.7$]$ seconds $(p=0.007$ [ $p=0.107]$, analysis using Student's t-test) (Table 7).

Thus, 12-week administration of Divaza led to a significant increase in the low density and very low density serum LP resistance to oxidation in comparison with placebo, which indicates an increase in antioxidant potential in patients with cerebral atherosclerosis.

\section{Secondary end point}

The percentage of patients with cognitive function improvement ( +1 and more points on the MoCA scale) in the course of treatment in the Divaza group after 12 weeks of treatment was 100\% [100\%], in the placebo group - 89.5\% [89.1\%] (Table 8). Thus, Divaza resulted in a statistically significant increase in the number of patients with improvement of mnemonic functions compared with patients receiving placebo in PP-analysis (Fisher criterion, $p=0.0272[p=0.0128])$.

Therefore, 12-week administration of Divaza led to an improvement in cognitive function in all patients.

\section{Additional end points}

After 12 weeks of treatment, the average level of preformed LPO products (mainly lipid hydroperoxides) decreased from $72.5 \pm 14.1$ [70.7 \pm 13.5$] \mathrm{mV}$ to $67.7 \pm 13.1[67.7 \pm 13.1] \mathrm{mV}$ in the Divaza group and from $72.8 \pm 12.9[72.7 \pm 12.3] \mathrm{mV}$ to $69.9 \pm 11.7[69.8 \pm 11.8] \mathrm{mV}$ in the placebo group. The average level of preformed LPO products after 12-week Divaza treatment in comparison with the baseline had decreased by $3.2 \pm 9.6$ [3.2 \pm 9.6 ] $\mathrm{mV}$ (compared to $2.9 \pm 8$ [3.2 \pm 7.9$] \mathrm{mV}$ decrease in the placebo group). The difference (value $\Delta$ ) between the groups was $0.3 \pm 8.8$ [0.004 \pm 8.760 ] mV. Statistical analysis using Student's t-test revealed no significant difference between the two groups $(p=0.8762)$. At the same time, the decrease in lipid hydroperoxide levels observed during 12 weeks of Divaza administration may indicate a reduction in the activity of LPO processes in patients with cerebral atherosclerosis.

After 12 weeks of treatment the average level of LP oxidation capacity decreased in the Divaza group from 1027.3 \pm 204.7 [1021.3 \pm 207.6 ] $\mathrm{mV}$ to 1024.1 \pm 226.7 [1024.1 \pm 226.7$] \mathrm{mV}$. However, in the placebo group it increased from 993.8 \pm 264.1 [973.8 \pm 259.7$] \mathrm{mV}$ to 1040.6 \pm 217.7 [1036.8 \pm 217.9$]$ $\mathrm{mV}$. The delta value for the Divaza and placebo groups between baseline and after 12 weeks therapy was $12.1 \pm 192.1 \mathrm{mV}$ and $57 \pm 241.5 \mathrm{mV}$, respectively. The difference (value $\Delta$ ) between the Divaza and placebo groups was $69.1 \pm 218.4 \mathrm{mV}[68.8 \pm 219.5]$ ), and was not statistically significant $(p=0.2082[p=0.2275]$, Wilcoxon test $)$.

\section{Safety assessment}

The safety and tolerability of therapy was evaluated in patients who received at least one dose of the study drug / Placebo (Safety population, $\mathrm{n}=123)$.

The study showed that Divaza administration did not have an impact on the vital signs of patients, including systolic and diastolic blood pressure, heart rate, and respiration rate.

8 AEs were recorded in 8 patients, including 5 AEs in 5 patients in the Divaza group and 3 AEs in 3 patients in the placebo group (Table 9 ).

Note: Data are presented as $\mathrm{n}(\%)$. The analysis was carried out using Fisher's exact test. Data are shown without correction for multiplicity of comparison.

No severe AEs were reported in either group. Frequency analysis showed no significant difference between the number of patients with AEs in the Divaza and placebo groups (Fischer's criterion; $p=0.72$ ). Frequency of AEs distribution depending on severity $(p=1.00)$ and presence/absence of cause-effect relation with the studied therapy $(p=1.00)$ did not differ between the two groups.

In the Divaza group, 4 (80\%) AEs were mild, 1 (20\%) - moderate; in the placebo group, 2 (66.7\%) AEs were mild and 1 (33.3\%) - moderate. Severe AEs have not been reported. The causal relationship of AEs with the study drug (Divaza) was absent in 4 cases ( $n=4 ; 80 \%$ ), and was possible in 1 case $(n=1 ; 20 \%)$. Not a single AEs with a reliable connection to the study medication (Divaza) was registered ( $p=1.00$, statistical calculations were performed using Fisher's exact test). The frequency of distribution of AEs depending on the severity $(p=1.00)$ and the presence / absence of a causal relationship with the study therapy $(p=1.00)$ did not differ in two groups.

Thus, the treatment was well-tolerated by patients and had a high compliance rate.

Page $7 / 25$ 


\title{
Discussion
}

An RCT was conducted in the Russian Federation and included 124 patients. The study evaluated the efficacy and safety of the drug Divaza for the correction of oxidative disturbances in patients with cerebral atherosclerosis.

In these adverse conditions, the use of natural or non-toxic synthetic antioxidants, which are inhibitors of free radical oxidation reactions, is feasible as therapeutic agents $[11,12]$. However, the limiting factors for the use of antioxidants in clinical practice are the low number of approved drugs, and insufficiently studied mechanisms of their action (due to complex methodological approaches to assess the antioxidant potential of substances) [30]. One of the most promising methods for studying the antioxidant activity of various biological substances is CL analysis [31, 32]. The advantage of $\mathrm{CL}$ reactions is their higher sensitivity and specificity compared to traditional biochemical methods [33].

The therapeutic effect of Divaza in patients with cerebral atherosclerosis is associated with a modifying effect on the functional activities of the brain-specific S-100 protein and eNOS. The brain-specific S-100 protein acts through the activation of receptors for advanced glycation end products (RAGE) located on the membranes of neurons and glial cells [34]. By binding to RAGE the brain-specific S-100 protein is involved in a number of biological functions: stabilization of membrane components, regulation of energy metabolism of cells, and cell proliferation. Due to the regulatory effect of the brain-specific S-100 protein on cell membranes, an increase in neuronal resistance to the toxic effects of LPO products is observed.

NO formed from L-arginine by eNOS in endothelial cells may have antioxidant activity, along with a vasodilating effect [35]. The antioxidant effect of NO is realized by increasing the activity of antioxidant enzymes, detoxification of oxygen radicals, and slowing down of LPO processes [36].

The current study demonstrated the antioxidant and nootropic effects of Divaza and increased brain resistance to toxic effects of LPO products. This was revealed by the positive dynamics of the corresponding OS indicators and improved cognitive function in all patients with cerebral atherosclerosis.

The Divaza effect revealed in this study is consistent with its previously described properties. In an in vivo model of sodium nitrite-induced acute hypoxia it was demonstrated that the combination of the TP Abs to S-100 and TP Abs to eNOS, as well as the reference compound mexidol, prevented or reduced activation of LPO in the brains of experimental animals, suggesting an antioxidant-like effect [37].

After a course of treatment, patients receiving the drug Divaza experienced a significant increase in the resistance of the low density and very low density serum LP to oxidation, which indicates the restoration of the activity of the endogenous antioxidant system. In the placebo group, this indicator remained depressed. Based on the data obtained, it can be concluded that Divaza possesses a pronounced antioxidant activity, significantly increases the resistance of the low density and very low density serum LP to oxidation, and thus exhibits protective properties towards lipid membranes in patients with CVD. The use of the drug Divaza in patients with cerebral atherosclerosis leads to a decrease in the severity of the most common clinical manifestations of this pathology - cognitive impairment.

\section{Conclusions}

Thus, it is advisable to conduct additional multicenter placebo-controlled studies of the efficacy and safety of the drug Divaza in order to correct oxidative and cognitive impairments.

\section{List Of Abbreviations}

\author{
AEs - adverse events \\ ATP - adenosine triphosphate \\ $\mathrm{CL}$ - iron-induced chemiluminescence \\ $\mathrm{Cl}$ - confidence interval \\ CVD - cerebrovascular disease \\ eNOS - endothelial NO synthase \\ FAS - full analysis set \\ GCP - good clinical practice \\ ITT - intention-to-treat \\ LP - lipoprotein \\ LPO - lipid peroxidation
}


Mean \pm SD - mean value and its standard deviation

MoCA - Montreal cognitive assessment

mRS - modified Rankin scale

NO - nitric oxide

OS - oxidative stress

PP - per protocol

RAGE - receptor for advanced glycation end products

RCT - randomized clinical trial

SAS-9.4 - statistical analysis system-9.4

TP Abs to eNOS - technologically processed highly diluted antibodies to the endothelial NO synthase

TP Abs to S-100 - technologically processed highly diluted antibodies to the brain specific S-100 protein

WHO - world health organization

\section{Declarations}

\section{Ethics approval and consent to participate}

The study was approved by the Ethics Council at the Ministry of Health of the Russian Federation (protocol № 161 of December 19, 2017) and local ethical committees of medical centers. All patients signed an informed consent form before enrollment.

\section{Consent for publication}

Obtained.

\section{Availability of data and material}

The study was registered at clinicaltrials.gov (NCT03485495).

\section{Competing interests}

Divaza is a preparation manufactured and marketed by 000 «NPF «MATERIA MEDICA HOLDING». Kamchatnov P.R., Fedorova T.N., Muzychuk O.A., Pizova N.V., Malygin A.U., Shavlovskaya O.A., Lashch N.U., Abrosimov A.V., Gerasimova Yu.A., Glushkov K.S., Lebedeva A.V. received an investigator grant from 000 «NPF «MATERIA MEDICA HOLDING» to conduct the clinical trials of Divaza, mentioned in this paper.

\section{Funding}

Studies mentioned in this paper of the combination of the technologically processed, highly diluted antibodies to the brain specific S-100 protein and the technologically processed, highly diluted antibodies to endothelial NO synthase were funded by a grant from OOO «NPF «MATERIA MEDICA HOLDING» (Moscow, Russian Federation). The funding body was involved in the development of the study protocol. Researchers participated in the collection, analysis and interpretation of data, as well as in the writing of the manuscript. The statistical analysis was provided by 000 «NPF «MATERIA MEDICA HOLDING».

\section{Authors' contributions}

TF, PK, NP, AM, OS were involved in the design of the study and contributed to writing and revising the manuscript. TF, VF, KN, PK, NP, AM, OS, NL, AA, $Y G, K G$, and $A L$ organized and managed the trial including trial start-up, data collection, quality assurance and trial close-out.

\section{Acknowledgements}

We thank the patients and families who volunteered for this study. We thank Dr. Kovalchuk A.L. for valuable comments on the paper and language editing. We also thank the laboratory for clinical and experimental neurochemistry at the Research Center of Neurology, Moscow, Russian Federation.

\section{References}


1. Parfyonov, V.A., Neverovsky, D.V. Management of patients with discirculatory encephalopathy in outpatient practice.Neurology, neuropsychiatry, psychosomatics. 2015; 1: 37-42. In Russian.

2. Izzo, C., Carrizzo, A., Alfano, A. The Impact of Aging on Cardio and Cerebrovascular Diseases.Int J Mol Sci. 2018;19(2):481. doi: 10.3390/ijms19020481.

3. World Health Organization (WHO). World Population Ageing: 1950-2050.

http://www.un.org/esa/population/publications/worldageing19502050/ (2016).

4. Kunz, A., ladecola, C. Cerebral vascular dysregulation in the ischemic brain.Handbook of clinical neurology. 2009;92:283-305. doi: 10.1016/S0072-9752(08)01914-3

5. Falkowska, A., Gutowska, I., Goschorska, M., Nowacki, P., Chlubek, D., Baranowska-Bosiacka, I. Energy Metabolism of the Brain, Including the Cooperation between Astrocytes and Neurons, Especially in the Context of Glycogen Metabolism.International journal of molecular sciences. 2015;16(11):25959-25981. doi: 10.3390/ijms161125939.

6. Camandola, S., Mattson, M.P. Brain metabolism in health, aging, and neurodegeneration. EMBO J. 2017;36:1474-1492. doi: 10.15252/embj.201695810

7. Higashi, Y., Noma, K., Yoshizumi, M., Kihara, Y. Endothelial function and oxidative stress in cardiovascular diseases.Circ J. 2009;73(3):411-418. Doi: $10.1253 /$ circj.cj-08-1102.

8. Chen, H., Yoshioka, H., Kim, G.S., Jung, J.E., Okami, N., Sakata, H., Maier, C.M., Narasimhan, P., Goeders, C.E., Chan, P.H. Oxidative stress in ischemic brain damage: mechanisms of cell death and potential molecular targets for neuroprotection.Antioxidants \& redox signaling. 2011;14(8):1505-1517. doi: 10.1089/ars.2010.3576.

9. Bhayadia, R., Schmidt, B.M., Melk, A., Homme, M. Senescence-Induced Oxidative Stress Causes Endothelial Dysfunction. J Gerontol A Biol Sci Med Sci. 2016;71(2):161-9. doi: 10.1093/gerona/glv008

10. Chen, S.D., Yang, D.I., Lin, T.K., Shaw, F.Z., Liou, C.W., Chuang, Y.C. Roles of oxidative stress, apoptosis, PGC-1a and mitochondrial biogenesis in cerebral ischemia. Int J Mol Sci. 2011;12:7199-7215. doi: 10.3390/ijms12107199.

11. Lobo, V., Patil, A., Phatak, A., Chandra, N. Free radicals, antioxidants and functional foods: Impact on human health.Pharmacognosy reviews. 2010;4(8):118-126. doi: 10.4103/0973-7847.70902.

12. Kurutas, E.B. The importance of antioxidants which play the role in cellular response against oxidative/nitrosative stress: current state.Nutrition journal. 2016;15(1):71. doi: 10.1186/s12937-016-0186-5.

13. Valavanidis, A., Vlachogianni, T., Fiotakis, K. Tobacco smoke: involvement of reactive oxygen species and stable free radicals in mechanisms of oxidative damage, carcinogenesis and synergistic effects with other respirable particles. International journal of environmental research and public health. 2009;6(2):445-462. doi: 10.3390/ijerph6020445.

14. Uttara, B., Singh, A.V., Zamboni, P., Mahajan, R.T. Oxidative stress and neurodegenerative diseases: a review of upstream and downstream antioxidant therapeutic options. Current neuropharmacology. 2009;7(1):65-74. doi: 10.2174/157015909787602823.

15. Rajendran, P., Rengarajan, T., Thangavel, J., Nishigaki, Y., Sakthisekaran, D., Sethi, G., Nishigaki, I. The vascular endothelium and human diseases.International journal of biological sciences. 2013;9(10):1057-1069. doi:10.7150/ijbs.7502.

16. Sandoo, A., van Zanten, J.J., Metsios, G.S., Carroll, D., Kitas, G.D. The endothelium and its role in regulating vascular tone. The open cardiovascular medicine journal. 2010;4:302-312. doi: 10.2174/1874192401004010302.

17. Cipolla, M.J. The Cerebral Circulation. San Rafael (CA): Morgan \& Claypool Life Sciences; 2009. Chapter 5, Control of Cerebral Blood Flow.

18. Fantini, S., Sassaroli, A., Tgavalekos, K.T., Kornbluth, J. Cerebral blood flow and autoregulation: current measurement techniques and prospects for noninvasive optical methods. 2016;3(3):031411. doi: 10.1117/1.NPh.3.3.031411.

19. Lee, J.M., Grabb, M.C., Zipfel, G.J., Choi, D.W. Brain tissue responses to ischemia.The Journal of clinical investigation. 2000;106(6):723-731. doi: $10.1172 / \mathrm{JCl} 11003$.

20. Phaniendra, A., Jestadi, D.B., Periyasamy, L. Free radicals: properties, sources, targets, and their implication in various diseases. Indian journal of clinical biochemistry.IJCB. 2015;30(1):11-26. doi: 10.1007/s12291-014-0446-0.

21. Parfenov, V.A., Ostroumova, O.D., Ostroumova, T.M., Kochetkov, A.I., Fateeva, V.V., Khacheva, K.K., Khakimova, G.R., Epstein, O.I. Vascular cognitive impairment: pathophysiological mechanisms, insights into structural basis, and perspectives in specific treatments. Neuropsychiatric disease and treatment. 2019;15:1381-1402. doi: 10.2147/NDT.S197032.

22. Vorob'eva, O.V., Fateeva, V.V., Nikulina, K.V., Khacheva, K.K., Khakimova, G.R., Epstein, O.I. Association between peripheral blood inflammatory markers, endothelial dysfunction markers, and depression. London: IntechOpen. 2019. doi:10.5772/intechopen.88693.

23. https://clinicaltrials.gov/ct2/show/NCT03485495

24. Vladimirov, Y.A., Packer, L., Traber, M.G., Xin, W. Natural Antioxidants: Molecular Mechanism and Health Effects. AOCS Press, Champaign, Illinois. 1996:125-144.

25. Fedorova, T.N., Us, K.S., Ostrovskaya, R.U. Evaluation of the antioxidant effect of the nootropic dipeptide noopept on the model of Fe ${ }^{2+}$-induced chemiluminescence of human serum lipoproteins in vitro. 2007;24(1):69-73. In Russian. 
26. Berezhnoy, D.S., Stvolinsky, S.L., Lopachev, A.V., et al. Carnosine as an effective neuroprotector in brain pathology and potential neuromodulator in normal conditions.Amino Acids. 2019;51(1):139-150. doi:10.1007/s00726-018-2667-7.

27. Kulikova, O.I., Berezhnoy, D.S., Stvolinsky, S.L., Lopachev, A.V., Orlova, V.S., Fedorova, T.N. Neuroprotective effect of the carnosine - a-lipoic acid nanomicellar complex in a model of early-stage Parkinson's disease.Regul Toxicol Pharmacol. 2018;95:254-259.

doi:10.1016/j.yrtph.2018.03.025.

28. Fedorova, T.N., Maksimova, M.Yu., Varakin, Yu.Ya., Gornostaeva, G.V., Logvinenko, A.A., Gnedovskaya, E.V., Suslina, Z.A. Oxidation of blood lipoproteins in patients with cerebrovascular accident.Annals of clinical and experimental neurology. 2014; 8 (1): 30-33. In Russian.

29. Parfenov, V.A., Kamchatnov, P.R., Vorobyova, O.V., Gustov, A.V., Glushkov, K.S., Doronina, O.B. The results of a multicenter study of the efficacy and safety of the use of the drug divaza in asthenic and mild or moderate cognitive impairment in the elderly and senile. Journal of Neurology and Psychiatry. 2017; 9: 43-50.

30. Kulikova, O.I., Stvolinsky, S.L., Migulin, V.A., et al. A new derivative of acetylsalicylic acid and camosine: synthesis, physical and chemical properties, biological activity.Daru. 2020;28(1):119-130. doi:10.1007/s40199-019-00323-x.

31. Vladimirov, G., Sergunova, E.V., Izmaylov, D.Yu., Vladimirov Yu.A. Chemiluminescent determination of total antioxidant capacity in medicinal plant material.Bulletin of Russian State Medical University. 2016;2:62-68.

32. Plotnikov, E., Korotkova, E., Voronova, O., Sazhina, N., Petrova, E., Artamonov, A., Chernyavskaya, L., Dorozhko, E. Comparative investigation of antioxidant activity of human serum blood by amperometric, voltammetric and chemiluminescent methods.rchives of medical science. 2016;12(5):1071-1076. doi: 10.5114/aoms.2015.50234.

33. Fedorova, T.N. The use of chemiluminescent analysis for the comparative evaluation of certain pharmacological substances. Experimental and clinical pharmacology. 2003;66(5):56-58. In Russian.

34. Bianchi, R., Kastrisianaki, E., Giambanco, I., Donato, R. S100B protein stimulates microglia migration via RAGE-dependent up-regulation of chemokine expression and release. The Journal of biological chemistry. 2011;286(9):7214-7226. doi: 10.1074/jbc.M110.169342.

35. Förstermann, U., Sessa, W.C. Nitric oxide synthases: regulation and function.European heart journal. 2012;33(7):829-837d. doi: 10.1093/eurheartj/ehr304.

36. Sharpe, M.A., Robb, S.J., Clark, J.B. Nitric oxide and Fenton/Haber-Weiss chemistry: nitric oxide is a potent antioxidant at physiological concentrations. J Neurochem. 2003;87(2):386- doi:10.1046/j.1471-4159.2003.02001.x.

37. Zhavbert, E.S., Guryanova, N.N., Surkova, E.I., Dugina, Y.L., Kachaeva, E.V., Epshtein, O.I. Divaza influence on the processes of lipid peroxidation. XXI Russian National Congress «Man and medicine»; April 7-11, 2014:242. In Russian.

\section{Tables}


Table 1

Patient demographics

\begin{tabular}{|c|c|c|c|c|}
\hline \multirow[t]{2}{*}{ Index } & \multicolumn{2}{|l|}{ Group } & \multirow[t]{2}{*}{ Total } & \multirow[t]{2}{*}{ Statistics } \\
\hline & Divaza & Placebo & & \\
\hline Total set & $n=65$ & $n=59$ & $n=124$ & \\
\hline Age, years & $61.4 \pm 7.8$ & $59.8 \pm 7.4$ & $60.7 \pm 7.6$ & $Z=1.43$ \\
\hline$M \pm S D$ & 62 & 60 & 61 & $p=0.15$ \\
\hline \multicolumn{5}{|l|}{ Median } \\
\hline Min & 43 & 40 & 40 & \\
\hline Max & 74 & 73 & 74 & \\
\hline Q1-Q3 & $57-68$ & $56-66$ & $57-67$ & \\
\hline Sex, n (\%) & $14(21.5)$ & 19 (32.2) & 33 (26.6) & $p=0.22$ \\
\hline Male & 51 (78.5) & $40(67.8)$ & 91 (73.4) & \\
\hline \multicolumn{5}{|l|}{ Female } \\
\hline ITT-analysis & $n=64$ & $n=59$ & $n=123$ & \\
\hline \multicolumn{5}{|l|}{ Age, years } \\
\hline$M \pm S D$ & $61.4 \pm 7.9$ & $59.8 \pm 7.4$ & $60.7 \pm 7.7$ & $Z=1.40$ \\
\hline Median & 62 & 60 & 61 & $p=0.16$ \\
\hline Min & 43 & 40 & 40 & \\
\hline Max & 74 & 73 & 74 & \\
\hline Q1-Q3 & $57-68$ & $56-66$ & $57-67$ & \\
\hline \multicolumn{5}{|l|}{ Sex, n (\%) } \\
\hline Male & $14(21.9)$ & 19 (32.2) & 33 (26.8) & $p=0.23$ \\
\hline Female & $50(78.1)$ & $40(67.8)$ & 90 (73.2) & \\
\hline PP-analysis & $n=56$ & $n=55$ & $n=111$ & \\
\hline \multicolumn{5}{|l|}{ Age, years } \\
\hline $\mathrm{M} \pm \mathrm{SD}$ & $61.3 \pm 7.8$ & $60.4 \pm 7.1$ & $60.8 \pm 7.5$ & $Z=0.84$ \\
\hline Median & 62 & 60 & 61 & $p=0.40$ \\
\hline Min & 43 & 40 & 40 & \\
\hline Max & 74 & 73 & 74 & \\
\hline Q1-Q3 & $57-68$ & $57-66$ & $57-67$ & \\
\hline \multicolumn{5}{|l|}{ Sex, n (\%) } \\
\hline Male & $13(23.2)$ & $17(30.9)$ & 30 (270) & $p=0.40$ \\
\hline Female & $43(76.8)$ & $38(69.1)$ & $81(73)$ & \\
\hline
\end{tabular}


Table 2

Baseline level of endogenous antioxidant potential

\begin{tabular}{|c|c|c|c|c|}
\hline \multirow[t]{2}{*}{ Index } & \multicolumn{2}{|c|}{ ITT-analysis $\left(n=122^{*}\right)$} & \multicolumn{2}{|c|}{ PP-analysis $(n=111)$} \\
\hline & Divaza $(n=63)$ & Placebo $(n=59)$ & Divaza $(n=56)$ & Placebo $(n=55)$ \\
\hline LP resistance to oxidation, (seconds) & $42.4 \pm 13.1$ & $42.9 \pm 11.2$ & $40.8 \pm 10.8$ & $42.2 \pm 10.9$ \\
\hline Mean \pm SD & 40 & 40 & 40 & 40 \\
\hline \multicolumn{5}{|l|}{ Median } \\
\hline Q1-Q3 & $33-50$ & $35-50$ & $33-47$ & $35-48$ \\
\hline $95 \% \mathrm{Cl}$ & $39.1-45.7$ & $40-45$ & $37.9-43.7$ & $39.2-45.2$ \\
\hline Statistics & \multicolumn{2}{|c|}{$Z=0.70 ; p=0.4825$} & \multicolumn{2}{|c|}{$Z=0.83 ; p=0.4070$} \\
\hline
\end{tabular}

Table 3

Baseline level of the preformed LPO products (mainly lipid hydroperoxides)

\begin{tabular}{|c|c|c|c|c|}
\hline \multirow[t]{2}{*}{ Index } & \multicolumn{2}{|c|}{ ITT-analysis $(n=122 *)$} & \multicolumn{2}{|c|}{ PP-analysis $(n=111)$} \\
\hline & Divaza $(n=63)$ & Placebo $(n=59)$ & Divaza $(n=56)$ & Placebo $(n=55)$ \\
\hline Preformed LPO products (mainly lipid hydroperoxides), mV & $72.5 \pm 14.1$ & $72.8 \pm 12.9$ & $70.7 \pm 13.5$ & $72.7 \pm 12.3$ \\
\hline Mean \pm SD & 71.9 & 71.1 & 69 & 71.1 \\
\hline \multicolumn{5}{|l|}{ Median } \\
\hline Q1-Q3 & $63-76$ & $64-79$ & $62-75$ & $64-79$ \\
\hline $95 \% \mathrm{Cl}$ & $68.9-76$ & $69.4-76.2$ & $67-74.3$ & $69.3-76$ \\
\hline Statistics & \multicolumn{2}{|c|}{$Z=0.19 ; p=0.8479$} & \multicolumn{2}{|c|}{$Z=0.95 ; p=0.3442$} \\
\hline
\end{tabular}

Table 4

Baseline level of LP oxidation capacity

\begin{tabular}{|c|c|c|c|c|}
\hline \multirow[t]{2}{*}{ Index } & \multicolumn{2}{|c|}{ ITT-analysis $(n=122 *)$} & \multicolumn{2}{|c|}{ PP-analysis $(n=111)$} \\
\hline & Divaza $(n=63)$ & Placebo $(n=59)$ & Divaza $(n=56)$ & Placebo $(n=55)$ \\
\hline LP oxidation capacity, mV & $1027.3 \pm 204.7$ & $993.8 \pm 264.1$ & $1021.3 \pm 207.6$ & $973.8 \pm 259.7$ \\
\hline Mean \pm SD & 1036 & 1028.5 & 1028 & 1011.2 \\
\hline \multicolumn{5}{|l|}{ Median } \\
\hline Q1-Q3 & $937.3-1182.7$ & $821-1171$ & $937-1186.3$ & $771-1171$ \\
\hline $95 \% \mathrm{Cl}$ & $975.3-1079.2$ & $924.3-1063.2$ & $965.1-1077.4$ & $902.9-1044.6$ \\
\hline Statistics & \multicolumn{2}{|l|}{$t=0.78 ; p=0.4369$} & \multicolumn{2}{|l|}{$Z=1.0 ; p=0.3188$} \\
\hline
\end{tabular}


Table 5

Comorbidities of study participants

\begin{tabular}{|c|c|c|c|c|c|c|c|}
\hline \multirow[t]{2}{*}{ System/organ/class } & \multirow[t]{2}{*}{ Disease } & \multicolumn{3}{|l|}{ ITT-analysis } & \multicolumn{3}{|l|}{ PP-analysis } \\
\hline & & Divaza $n=64$ & Placebo $n=59$ & $\begin{array}{l}\mathrm{p}- \\
\text { value }\end{array}$ & Divaza $n=56$ & $\begin{array}{l}\text { Placebo } n= \\
55\end{array}$ & p-value \\
\hline \multicolumn{2}{|c|}{$\begin{array}{l}\text { Total patients with at least one concomitant } \\
\text { disease }\end{array}$} & $60(93.8)$ & $55(93.2)$ & 1.000 & $54(96.4)$ & $53(96.4)$ & 1.000 \\
\hline \multirow[t]{8}{*}{ Vascular disease } & Arterial hypertension & $19(29.7)$ & $15(25.4)$ & & $16(28.6)$ & $15(27.3)$ & \\
\hline & $\begin{array}{l}\text { Atherosclerosis of } \\
\text { the aorta }\end{array}$ & $0(0)$ & $2(3.4)$ & & $0(0)$ & $2(3.6)$ & \\
\hline & $\begin{array}{l}\text { Varicose veins of the } \\
\text { lower extremities }\end{array}$ & $2(3.1)$ & $3(1.0)$ & & $2(3.6)$ & $3(1.0)$ & \\
\hline & Labile hypertension & $0(0)$ & $1(1.7)$ & & $0(0)$ & $1(1.8)$ & \\
\hline & $\begin{array}{l}\text { Obliterating } \\
\text { atherosclerosis of } \\
\text { the vessels of the } \\
\text { lower extremities }\end{array}$ & $1(1.6)$ & $0(0)$ & & $1(1.8)$ & $0(0)$ & \\
\hline & $\begin{array}{l}\text { Chronic venous } \\
\text { insufficiency }\end{array}$ & $1(1.6)$ & $1(1.7)$ & & $1(1.8)$ & $1(1.8)$ & \\
\hline & $\begin{array}{l}\text { Essential } \\
\text { hypertension }\end{array}$ & $36(56.3)$ & $35(59.3)$ & & $33(58.9)$ & $33(60.0)$ & \\
\hline & $\begin{array}{l}\text { The number of } \\
\text { patients with at least } \\
\text { one disease in this } \\
\text { group }\end{array}$ & $55(85.9)$ & $52(88.1)$ & 0.793 & $49(87.5)$ & $50(90.1)$ & 0.761 \\
\hline \multirow[t]{14}{*}{$\begin{array}{l}\text { Diseases of the } \\
\text { nervous system }\end{array}$} & $\begin{array}{l}\text { Atherosclerosis of } \\
\text { cerebral vessels }\end{array}$ & $0(0)$ & $1(1.7)$ & & $0(0)$ & $1(1.8)$ & \\
\hline & $\begin{array}{l}\text { Vertebrobasilar } \\
\text { insufficiency }\end{array}$ & $1(1.6)$ & $1(1.7)$ & & $1(1.8)$ & $1(1.8)$ & \\
\hline & $\begin{array}{l}\text { Vertebrobasilar } \\
\text { stroke }\end{array}$ & $1(1.6)$ & $1(1.7)$ & & $1(1.8)$ & $1(1.8)$ & \\
\hline & $\begin{array}{l}\text { Hypertensive } \\
\text { encephalopathy }\end{array}$ & $1(1.6)$ & $0(0)$ & & $1(1.8)$ & $0(0)$ & \\
\hline & $\begin{array}{l}\text { Tortuosity of the } \\
\text { internal carotid artery }\end{array}$ & $2(3.1)$ & $0(0)$ & & $2(3.6)$ & $0(0)$ & \\
\hline & $\begin{array}{l}\text { Heart attack in the } \\
\text { basin of the middle } \\
\text { cerebral artery }\end{array}$ & $4(6.3)$ & $0(0)$ & & $4(7.1)$ & $0(0)$ & \\
\hline & Migraine with aura & $0(0)$ & $1(1.7)$ & & $0(0)$ & $1(1.8)$ & \\
\hline & $\begin{array}{l}\text { Long-term } \\
\text { consequences of } \\
\text { poliomyelitis }\end{array}$ & $0(0)$ & $1(1.7)$ & & $0(0)$ & $1(1.8)$ & \\
\hline & $\begin{array}{l}\text { Pyramidal } \\
\text { insufficiency }\end{array}$ & $1(1.6)$ & $1(1.7)$ & & $1(1.8)$ & $1(1.8)$ & \\
\hline & Polyneuropathy & $1(1.6)$ & $0(0)$ & & $1(1.8)$ & $0(0)$ & \\
\hline & $\begin{array}{l}\text { The consequences } \\
\text { of a stroke }\end{array}$ & $1(1.6)$ & $1(1.7)$ & & $1(1.8)$ & $1(1.8)$ & \\
\hline & Simple migraine & $1(1.6)$ & $0(0)$ & & $1(1.8)$ & $0(0)$ & \\
\hline & $\begin{array}{l}\text { Recurrent ipsilateral } \\
\text { stroke }\end{array}$ & $1(1.6)$ & $0(0)$ & & $1(1.8)$ & $0(0)$ & \\
\hline & $\begin{array}{l}\text { Vascular } \\
\text { encephalopathy }\end{array}$ & $2(3.1)$ & $1(1.7)$ & & $2(3.6)$ & $1(1.8)$ & \\
\hline
\end{tabular}




\begin{tabular}{|c|c|c|c|c|c|c|c|c|}
\hline \multirow[t]{6}{*}{ System/organ/class } & \multirow{3}{*}{$\begin{array}{l}\text { Disease } \\
\begin{array}{l}\text { Chronic cerebral } \\
\text { ischemia }\end{array}\end{array}$} & \multicolumn{4}{|c|}{ ITT-analysis } & \multicolumn{3}{|l|}{ PP-analysis } \\
\hline & & \multicolumn{2}{|c|}{ Divaza $\mathrm{n}=64$} & \multirow{2}{*}{$\begin{array}{l}\text { Placebo } \mathbf{n}=59 \\
0(0)\end{array}$} & \multirow[t]{2}{*}{$\begin{array}{l}\mathrm{p} \text { - } \\
\text { value }\end{array}$} & Divaza $\mathrm{n}=56$ & $\begin{array}{l}\text { Placebo } n= \\
55\end{array}$ & $\mathrm{p}$-value \\
\hline & & $3(4.7)$ & & & & $3(5.4)$ & $0(0)$ & \\
\hline & Cerebral infarction & $0(0)$ & & $1(1.7)$ & & $0(0)$ & $1(1.8)$ & \\
\hline & $\begin{array}{l}\text { Circulatory } \\
\text { encephalopathy }\end{array}$ & $5(7.8)$ & & $2(3.4)$ & & $5(8.9)$ & $2(3.6)$ & \\
\hline & $\begin{array}{l}\text { The number of } \\
\text { patients with at least } \\
\text { one disease in this } \\
\text { group }\end{array}$ & $15(23.4)$ & & $7(11.9)$ & 0.106 & $15(26.8)$ & $7(12.7)$ & 0.095 \\
\hline \multirow{2}{*}{$\begin{array}{l}\text { Congenital, familial } \\
\text { and genetic } \\
\text { diseases }\end{array}$} & $\begin{array}{l}\text { Vertebral artery } \\
\text { hypoplasia }\end{array}$ & $1(1.6)$ & & $0(0)$ & & $0(0)$ & $0(0)$ & \\
\hline & $\begin{array}{l}\text { The number of } \\
\text { patients with at least } \\
\text { one disease in this } \\
\text { group }\end{array}$ & $1(1.6)$ & & $0(0)$ & 1.000 & $0(0)$ & $0(0)$ & - \\
\hline \multirow{3}{*}{$\begin{array}{l}\text { Benign, malignant, } \\
\text { and unspecified } \\
\text { neoplasms } \\
\text { (including cysts and } \\
\text { polyps) }\end{array}$} & Prostate adenoma & $2(3.1)$ & & $0(0)$ & & $2(3.6)$ & $0(0)$ & \\
\hline & Myoma of the uterus & $1(1.6)$ & & $2(3.4)$ & & $1(1.8)$ & $2(3.6)$ & \\
\hline & $\begin{array}{l}\text { The number of } \\
\text { patients with at least } \\
\text { one disease in this } \\
\text { group }\end{array}$ & $3(4.7)$ & & $2(3.4)$ & 1.000 & $3(4.7)$ & $2(3.6)$ & 1.000 \\
\hline \multirow{7}{*}{$\begin{array}{l}\text { Gastrointestinal } \\
\text { diseases }\end{array}$} & Duodenal ulcer & $2(3.1)$ & & $1(1.7)$ & & $2(3.6)$ & $1(1.8)$ & \\
\hline & $\begin{array}{l}\text { Pancreatic } \\
\text { lipomatosis }\end{array}$ & $0(0)$ & & $1(1.7)$ & & $0(0)$ & $1(1.8)$ & \\
\hline & Chronic gastritis & $5(7.8)$ & & $7(11.9)$ & & $2(3.6)$ & $7(12.7)$ & \\
\hline & $\begin{array}{l}\text { Chronic } \\
\text { gastroduodenitis }\end{array}$ & $1(1.6)$ & & $0(0)$ & & $1(1.8)$ & $0(0)$ & \\
\hline & Chronic pancreatitis & $4(6.3)$ & & $3(5.1)$ & & $3(5.4)$ & $3(5.5)$ & \\
\hline & Stomach ulcer & $0(0)$ & & $2(3.4)$ & & $0(0)$ & $2(3.6)$ & \\
\hline & $\begin{array}{l}\text { The number of } \\
\text { patients with at least } \\
\text { one disease in this } \\
\text { group }\end{array}$ & $8(12.5)$ & & $12(20.3)$ & 0.329 & $5(8.9)$ & $12(21.8)$ & 0.070 \\
\hline \multirow{4}{*}{$\begin{array}{l}\text { Infections and } \\
\text { invasions }\end{array}$} & Onychomycosis & $1(1.6)$ & & $0(0)$ & & $1(1.8)$ & $0(0)$ & \\
\hline & $\begin{array}{l}\text { Chronic } \\
\text { pyelonephritis }\end{array}$ & $1(1.6)$ & & $0(0)$ & & $1(1.8)$ & $0(0)$ & \\
\hline & Chronic rhinitis & $1(1.6)$ & & $0(0)$ & & $1(1.8)$ & $0(0)$ & \\
\hline & $\begin{array}{l}\text { The number of } \\
\text { patients with at least } \\
\text { one disease in this } \\
\text { group }\end{array}$ & $3(4.7)$ & & $0(0)$ & 0.245 & $3(4.7)$ & $0(0)$ & 0.243 \\
\hline \multirow[t]{3}{*}{$\begin{array}{l}\text { Laboratory and } \\
\text { instrumental data }\end{array}$} & $\begin{array}{l}\text { Abnormal abdominal } \\
\text { results }\end{array}$ & Itrasound & $1(1.6)$ & $0(0)$ & & $1(1.8)$ & $0(0)$ & \\
\hline & Abnormal liver ultraso & Ind results & $2(3.1)$ & $0(0)$ & & $2(3.6)$ & $0(0)$ & \\
\hline & $\begin{array}{l}\text { The number of patient } \\
\text { least one disease in th }\end{array}$ & $\begin{array}{l}\text { with at } \\
\text { s group }\end{array}$ & $2(3.1)$ & $0(0)$ & 0.497 & $2(3.6)$ & $0(0)$ & 0.500 \\
\hline \multirow{2}{*}{$\begin{array}{l}\text { Eating and } \\
\text { metabolic disorders }\end{array}$} & Dyslipidemia & $13(20.3)$ & & $13(22.0)$ & & $12(21.4)$ & $13(23.6)$ & \\
\hline & $\begin{array}{l}\text { Non-insulin } \\
\text { dependent diabetes } \\
\text { mellitus }\end{array}$ & $0(0)$ & & $1(1.7)$ & & $0(0)$ & $1(1.8)$ & \\
\hline
\end{tabular}

Notes. Data are presented as n (\%). Frequency analysis was performed using Fisher's exact test. Results are given without correction for multiplicity of comparison. 


\begin{tabular}{|c|c|c|c|c|c|c|c|}
\hline \multirow[t]{2}{*}{ System/organ/class } & \multirow[t]{2}{*}{ Disease } & \multicolumn{3}{|l|}{ ITT-analysis } & \multicolumn{3}{|l|}{ PP-analysis } \\
\hline & & Divaza $n=64$ & Placebo $n=59$ & $\begin{array}{l}\mathrm{p}- \\
\text { value }\end{array}$ & Divaza $n=56$ & $\begin{array}{l}\text { Placebo } n= \\
55\end{array}$ & p-value \\
\hline & Morbid obesity & $1(1.6)$ & $0(0)$ & & $1(1.8)$ & $0(0)$ & \\
\hline & Obesity & $4(6.3)$ & $2(3.4)$ & & $3(5.4)$ & $2(3.6)$ & \\
\hline & $\begin{array}{l}\text { Type } 2 \text { diabetes } \\
\text { mellitus }\end{array}$ & $9(14.1)$ & $1(1.7)$ & & $7(12.5)$ & $1(1.8)$ & \\
\hline & $\begin{array}{l}\text { The number of } \\
\text { patients with at least } \\
\text { one disease in this } \\
\text { group }\end{array}$ & $20(31.3)$ & $14(23.7)$ & 0.421 & $16(28.6)$ & $14(25.5)$ & 0.831 \\
\hline \multirow{6}{*}{$\begin{array}{l}\text { Diseases of the } \\
\text { respiratory system, } \\
\text { chest and } \\
\text { mediastinal organs }\end{array}$} & Atopic asthma & $0(0)$ & $2(3.4)$ & & $0(0)$ & $2(3.6)$ & \\
\hline & Bronchitis, chronic & $0(0)$ & $1(1.7)$ & & $0(0)$ & $1(1.8)$ & \\
\hline & Vasomotor rhinitis & $0(0)$ & $1(1.7)$ & & $0(0)$ & $1(1.8)$ & \\
\hline & $\begin{array}{l}\text { Cyst in the maxillary } \\
\text { sinus }\end{array}$ & $1(1.6)$ & $0(0)$ & & $1(1.8)$ & $0(0)$ & \\
\hline & $\begin{array}{l}\text { Chronic obstructive } \\
\text { bronchitis }\end{array}$ & $2(3.1)$ & $1(1.7)$ & & $2(3.6)$ & $1(1.8)$ & \\
\hline & $\begin{array}{l}\text { The number of } \\
\text { patients with at least } \\
\text { one disease in this } \\
\text { group }\end{array}$ & $3(4.7)$ & $5(8.5)$ & 0.479 & $3(5.4)$ & $5(9.1)$ & 0.489 \\
\hline \multirow[t]{2}{*}{$\begin{array}{l}\text { Diseases of the } \\
\text { immune system }\end{array}$} & $\begin{array}{l}\text { Allergic reaction to } \\
\text { antibiotics }\end{array}$ & $0(0)$ & $1(1.7)$ & & $0(0)$ & $1(1.8)$ & \\
\hline & $\begin{array}{l}\text { The number of } \\
\text { patients with at least } \\
\text { one disease in this } \\
\text { group }\end{array}$ & $0(0)$ & $1(1.7)$ & 0.480 & $0(0)$ & $1(1.8)$ & 0.500 \\
\hline \multirow{4}{*}{$\begin{array}{l}\text { Diseases of the skin } \\
\text { and subcutaneous } \\
\text { tissue }\end{array}$} & Vitiligo & $1(1.6)$ & $0(0)$ & & $1(1.8)$ & $0(0)$ & \\
\hline & Cyst, epidermal & $0(0)$ & $1(1.7)$ & & $0(0)$ & $1(1.8)$ & \\
\hline & Chronic eczema & $0(0)$ & $1(1.7)$ & & $0(0)$ & $1(1.8)$ & \\
\hline & $\begin{array}{l}\text { The number of } \\
\text { patients with at least } \\
\text { one disease in this } \\
\text { group }\end{array}$ & $1(1.6)$ & $2(3.4)$ & 0.607 & $1(1.8)$ & $2(3.6)$ & 0.618 \\
\hline \multirow{2}{*}{$\begin{array}{l}\text { Diseases of the } \\
\text { blood and lymphatic } \\
\text { system }\end{array}$} & $\begin{array}{l}\text { Iron-deficiency } \\
\text { anemia }\end{array}$ & $0(0)$ & $1(1.7)$ & & $0(0)$ & $1(1.8)$ & \\
\hline & $\begin{array}{l}\text { The number of } \\
\text { patients with at least } \\
\text { one disease in this } \\
\text { group }\end{array}$ & $0(0)$ & $1(1.7)$ & 0.480 & $0(0)$ & $1(1.8)$ & 0.500 \\
\hline \multirow{7}{*}{$\begin{array}{l}\text { Diseases of muscle, } \\
\text { skeletal and } \\
\text { connective tissue }\end{array}$} & $\begin{array}{l}\text { Arthritis of the joints } \\
\text { of the hand }\end{array}$ & $0(0)$ & $1(1.7)$ & & $0(0)$ & $1(1.8)$ & \\
\hline & Hallux valgus & $0(0)$ & $1(1.7)$ & & $0(0)$ & $1(1.8)$ & \\
\hline & $\begin{array}{l}\text { Generalized } \\
\text { osteoarthritis }\end{array}$ & $2(3.1)$ & $0(0)$ & & $2(3.6)$ & $0(0)$ & \\
\hline & Gonarthrosis & $2(3.1)$ & $0(0)$ & & $2(3.6)$ & $0(0)$ & \\
\hline & Coxarthrosis & $1(1.6)$ & $0(0)$ & & $1(1.8)$ & $0(0)$ & \\
\hline & $\begin{array}{l}\text { Dupuytren's } \\
\text { contracture }\end{array}$ & $1(1.6)$ & $0(0)$ & & $1(1.8)$ & $0(0)$ & \\
\hline & $\begin{array}{l}\text { Osteoarthritis of the } \\
\text { temporomandibular } \\
\text { joint }\end{array}$ & $0(0)$ & $1(1.7)$ & & $0(0)$ & $1(1.8)$ & \\
\hline
\end{tabular}

Notes. Data are presented as $\mathrm{n}(\%)$. Frequency analysis was performed using Fisher's exact test. Results are given without correction for multiplicity of comparison. 


\begin{tabular}{|c|c|c|c|c|c|c|c|}
\hline \multirow[t]{2}{*}{ System/organ/class } & \multirow[t]{2}{*}{ Disease } & \multicolumn{3}{|l|}{ ITT-analysis } & \multicolumn{3}{|l|}{ PP-analysis } \\
\hline & & Divaza $\mathrm{n}=64$ & Placebo $n=59$ & $\begin{array}{l}\mathrm{p}- \\
\text { value }\end{array}$ & Divaza $n=56$ & $\begin{array}{l}\text { Placebo } n= \\
55\end{array}$ & p-value \\
\hline & Ankle osteoarthritis & $0(0)$ & $1(1.7)$ & & $0(0)$ & $1(1.8)$ & \\
\hline & $\begin{array}{l}\text { Osteoarthritis of the } \\
\text { hand }\end{array}$ & $0(0)$ & $1(1.7)$ & & $0(0)$ & $1(1.8)$ & \\
\hline & Osteoporosis & $1(1.6)$ & $0(0)$ & & $1(1.8)$ & $0(0)$ & \\
\hline & $\begin{array}{l}\text { Osteocondritis of the } \\
\text { spine }\end{array}$ & $15(23.4)$ & $13(22.0)$ & & $14(25.0)$ & 13 (23.6) & \\
\hline & Flat feet & $0(0)$ & $1(1.7)$ & & $0(0)$ & $1(1.8)$ & \\
\hline & Gouty arthritis & $0(0)$ & $1(1.7)$ & & $0(0)$ & $1(1.8)$ & \\
\hline & $\begin{array}{l}\text { Postmenopausal } \\
\text { osteoporosis }\end{array}$ & $1(1.6)$ & $0(0)$ & & $1(1.0)$ & $0(0)$ & \\
\hline & $\begin{array}{l}\text { The number of } \\
\text { patients with at least } \\
\text { one disease in this } \\
\text { group }\end{array}$ & $18(28.1)$ & $16(27.1)$ & 1.000 & $17(30.4)$ & $16(29.1)$ & 1.000 \\
\hline \multirow{12}{*}{$\begin{array}{l}\text { Diseases of the } \\
\text { organ of vision }\end{array}$} & Retinal angiopathy & $1(1.6)$ & $0(0)$ & & $1(1.8)$ & $0(0)$ & \\
\hline & Bilateral cataract & $1(1.6)$ & $0(0)$ & & $1(1.8)$ & $0(0)$ & \\
\hline & Cataract & $2(3.1)$ & $2(3.4)$ & & $2(3.6)$ & $2(3.6)$ & \\
\hline & Macular dystrophy & $1(1.6)$ & $0(0)$ & & $1(1.8)$ & $0(0)$ & \\
\hline & Myopia & $1(1.6)$ & $0(0)$ & & $1(1.8)$ & $0(0)$ & \\
\hline & Initial senile cataract & $0(0)$ & $1(1.7)$ & & $0(0)$ & $1(1.8)$ & \\
\hline & $\begin{array}{l}\text { Complicated } \\
\text { cataract }\end{array}$ & $0(0)$ & $1(1.7)$ & & $0(0)$ & $1(1.8)$ & \\
\hline & $\begin{array}{l}\text { Open angle } \\
\text { glaucoma }\end{array}$ & $0(0)$ & $1(1.7)$ & & $0(0)$ & $1(1.8)$ & \\
\hline & Presbyopia & $1(1.6)$ & $2(3.4)$ & & $1(1.8)$ & $2(3.6)$ & \\
\hline & $\begin{array}{l}\text { Retinal vascular } \\
\text { spasm }\end{array}$ & $0(0)$ & $1(1.7)$ & & $0(0)$ & $1(1.8)$ & \\
\hline & Epiretinal membrane & $0(0)$ & $1(1.7)$ & & $0(0)$ & $1(1.8)$ & \\
\hline & $\begin{array}{l}\text { The number of } \\
\text { patients with at least } \\
\text { one disease in this } \\
\text { group }\end{array}$ & $4(6.3)$ & $5(8.5)$ & 0.736 & $4(7.1)$ & $5(9.1)$ & 0.742 \\
\hline \multirow{5}{*}{$\begin{array}{l}\text { Diseases of the } \\
\text { organ of hearing } \\
\text { and labyrinth }\end{array}$} & Vestibular pathology & $3(4.7)$ & $0(0)$ & & $3(5.4)$ & $0(0)$ & \\
\hline & Conductive deafness & $0(0)$ & $1(1.7)$ & & $0(0)$ & $1(1.8)$ & \\
\hline & $\begin{array}{l}\text { Sensorineural } \\
\text { deafness }\end{array}$ & $1(1.6)$ & $1(1.7)$ & & $1(1.8)$ & $1(1.8)$ & \\
\hline & Hearing loss & $1(1.6)$ & $0(0)$ & & $1(1.8)$ & $0(0)$ & \\
\hline & $\begin{array}{l}\text { The number of } \\
\text { patients with at least } \\
\text { one disease in this } \\
\text { group }\end{array}$ & $5(7.8)$ & $2(3.4)$ & 0.442 & $5(8.9)$ & $2(3.6)$ & 0.438 \\
\hline \multirow{4}{*}{$\begin{array}{l}\text { Diseases of the liver } \\
\text { and biliary tract }\end{array}$} & Hepatosis & $0(0)$ & $1(1.7)$ & & $0(0)$ & $1(1.8)$ & \\
\hline & Hepatosplenomegaly & $1(1.6)$ & $0(0)$ & & $1(1.8)$ & $0(0)$ & \\
\hline & Biliary dyskinesia & $1(1.6)$ & $0(0)$ & & $1(1.8)$ & $0(0)$ & \\
\hline & Fatty hepatosis & $1(1.6)$ & $1(1.7)$ & & $1(1.8)$ & $1(1.8)$ & \\
\hline
\end{tabular}

Notes. Data are presented as n (\%). Frequency analysis was performed using Fisher's exact test. Results are given without correction for multiplicity of comparison. 


\begin{tabular}{|c|c|c|c|c|c|c|c|}
\hline \multirow[t]{2}{*}{ System/organ/class } & \multirow[t]{2}{*}{ Disease } & \multicolumn{3}{|l|}{ ITT-analysis } & \multicolumn{3}{|l|}{ PP-analysis } \\
\hline & & Divaza $\mathrm{n}=64$ & Placebo $n=59$ & $\begin{array}{l}\mathrm{p}- \\
\text { value }\end{array}$ & Divaza $\mathrm{n}=56$ & $\begin{array}{l}\text { Placebo } n= \\
55\end{array}$ & p-value \\
\hline & Hepatic cyst & $0(0)$ & $1(1.7)$ & & $0(0)$ & $1(1.8)$ & \\
\hline & Cholelithiasis & $0(0)$ & $1(1.7)$ & & $0(0)$ & $1(1.8)$ & \\
\hline & $\begin{array}{l}\text { Chronic acalculous } \\
\text { cholecystitis }\end{array}$ & $1(1.6)$ & $0(0)$ & & $1(1.8)$ & $0(0)$ & \\
\hline & $\begin{array}{l}\text { Chronic calculous } \\
\text { cholecystitis }\end{array}$ & $0(0)$ & $1(1.7)$ & & $0(0)$ & $1(1.8)$ & \\
\hline & Chronic cholecystitis & $1(1.6)$ & $0(0)$ & & $0(0)$ & $0(0)$ & \\
\hline & Chronic cholecystitis & $2(3.1)$ & $2(3.4)$ & & $1(1.8)$ & $2(3.6)$ & \\
\hline & $\begin{array}{l}\text { The number of } \\
\text { patients with at least } \\
\text { one disease in this } \\
\text { group }\end{array}$ & $6(9.4)$ & $6(10.2)$ & 1.000 & $4(7.1)$ & $6(10.9)$ & 0.527 \\
\hline \multirow{3}{*}{$\begin{array}{l}\text { Kidney and urinary } \\
\text { tract diseases }\end{array}$} & Kidney cyst & $1(1.6)$ & $0(0)$ & & $1(1.8)$ & $0(0)$ & \\
\hline & Nephrolithiasis & $1(1.6)$ & $1(1.7)$ & & $1(1.8)$ & $1(1.8)$ & \\
\hline & $\begin{array}{l}\text { The number of } \\
\text { patients with at least } \\
\text { one disease in this } \\
\text { group }\end{array}$ & $2(3.1)$ & $1(1.7)$ & 1.000 & $2(3.6)$ & $1(1.8)$ & 1.000 \\
\hline \multirow{8}{*}{$\begin{array}{l}\text { Diseases of the } \\
\text { reproductive system } \\
\text { and mammary } \\
\text { glands }\end{array}$} & Atrophic vaginitis & $1(1.6)$ & $1(1.7)$ & & $1(1.8)$ & $1(1.8)$ & \\
\hline & $\begin{array}{l}\text { Vaginal prolapse } \\
\text { grade } 2\end{array}$ & $0(0)$ & $1(1.7)$ & & $0(0)$ & $1(1.8)$ & \\
\hline & $\begin{array}{l}\text { Prolapsed uterus and } \\
\text { vagina }\end{array}$ & $1(1.6)$ & $0(0)$ & & $1(1.8)$ & $0(0)$ & \\
\hline & $\begin{array}{l}\text { Hyperplasia of the } \\
\text { prostate }\end{array}$ & $1(1.6)$ & $0(0)$ & & $1(1.8)$ & $0(0)$ & \\
\hline & $\begin{array}{l}\text { Endometrial } \\
\text { hyperplasia }\end{array}$ & $0(0)$ & $1(1.7)$ & & $0(0)$ & $1(1.8)$ & \\
\hline & Vaginal prolapse & $1(1.6)$ & $0(0)$ & & $1(1.8)$ & $0(0)$ & \\
\hline & Chronic prostatitis & $2(3.1)$ & $0(0)$ & & $2(3.6)$ & $0(0)$ & \\
\hline & $\begin{array}{l}\text { The number of } \\
\text { patients with at least } \\
\text { one disease in this } \\
\text { group }\end{array}$ & $6(9.4)$ & $2(3.4)$ & 0.276 & $6(10.7)$ & $2(3.6)$ & 0.271 \\
\hline \multirow[t]{9}{*}{ Heart diseases } & $\begin{array}{l}\text { Postinfarction } \\
\text { cardiosclerosis }\end{array}$ & $0(0)$ & $2(3.4)$ & & $0(0)$ & $2(3.6)$ & \\
\hline & $\begin{array}{l}\text { Permanent form of } \\
\text { atrial fibrillation }\end{array}$ & $1(1.6)$ & $0(0)$ & & $1(1.8)$ & $0(0)$ & \\
\hline & $\begin{array}{l}\text { Heart failure class I } \\
\text { NYHA }\end{array}$ & $1(1.6)$ & $1(1.7)$ & & $1(1.8)$ & $1(1.8)$ & \\
\hline & $\begin{array}{l}\text { Heart failure class II } \\
\text { NYHA }\end{array}$ & $1(1.6)$ & $1(1.7)$ & & $1(1.8)$ & $1(1.8)$ & \\
\hline & Sinus tachycardia & $3(4.7)$ & $1(1.7)$ & & $3(5.4)$ & $1(1.8)$ & \\
\hline & $\begin{array}{l}\text { Stable exertional } \\
\text { angina }\end{array}$ & $0(0)$ & $1(1.7)$ & & $0(0)$ & $1(1.8)$ & \\
\hline & Exertional angina & $2(3.1)$ & $1(1.7)$ & & $2(3.6)$ & $1(1.8)$ & \\
\hline & Chronic heart failure & $0(0)$ & $2(3.4)$ & & $0(0)$ & $2(3.6)$ & \\
\hline & Extrasystole & $0(0)$ & $1(1.7)$ & & $0(0)$ & $1(1.8)$ & \\
\hline
\end{tabular}




\begin{tabular}{|c|c|c|c|c|c|c|c|}
\hline \multirow[t]{2}{*}{ System/organ/class } & \multirow[t]{2}{*}{ Disease } & \multicolumn{3}{|l|}{ ITT-analysis } & \multicolumn{3}{|l|}{ PP-analysis } \\
\hline & & Divaza $\mathrm{n}=64$ & Placebo $n=59$ & $\begin{array}{l}\mathrm{p}- \\
\text { value }\end{array}$ & Divaza $\mathrm{n}=56$ & $\begin{array}{l}\text { Placebo } n= \\
55\end{array}$ & p-value \\
\hline & $\begin{array}{l}\text { The number of } \\
\text { patients with at least } \\
\text { one disease in this } \\
\text { group }\end{array}$ & $8(12.5)$ & $8(13.6)$ & 1.000 & $8(14.3)$ & $8(14.5)$ & 1.000 \\
\hline \multirow{5}{*}{$\begin{array}{l}\text { Surgical and } \\
\text { conservative } \\
\text { treatment } \\
\text { procedures }\end{array}$} & $\begin{array}{l}\text { Thyroid hormone } \\
\text { replacement therapy }\end{array}$ & $1(1.6)$ & $0(0)$ & & $1(1.8)$ & $0(0)$ & \\
\hline & $\begin{array}{l}\text { Supravaginal } \\
\text { hysterectomy }\end{array}$ & $1(1.6)$ & $0(0)$ & & $1(1.8)$ & $0(0)$ & \\
\hline & $\begin{array}{l}\text { Surgical treatment of } \\
\text { glaucoma }\end{array}$ & $0(0)$ & $1(1.7)$ & & $0(0)$ & $1(1.8)$ & \\
\hline & Thyroid surgery & $0(0)$ & $1(1.7)$ & & $0(0)$ & $1(1.8)$ & \\
\hline & $\begin{array}{l}\text { The number of } \\
\text { patients with at least } \\
\text { one disease in this } \\
\text { group }\end{array}$ & $2(3.1)$ & $2(3.4)$ & 1.000 & $2(3.6)$ & $2(3.6)$ & 1.000 \\
\hline \multirow{2}{*}{$\begin{array}{l}\text { Social } \\
\text { circumstances }\end{array}$} & Postmenopause & $0(0)$ & $1(1.7)$ & & $0(0)$ & $1(1.8)$ & \\
\hline & $\begin{array}{l}\text { The number of } \\
\text { patients with at least } \\
\text { one disease in this } \\
\text { group }\end{array}$ & $0(0)$ & $1(1.7)$ & 0.480 & $0(0)$ & $1(1.8)$ & 0.500 \\
\hline \multirow[t]{8}{*}{$\begin{array}{l}\text { Diseases of the } \\
\text { thyroid gland }\end{array}$} & $\begin{array}{l}\text { Autoimmune } \\
\text { thyroiditis }\end{array}$ & $2(3.1)$ & $1(1.7)$ & & $2(3.6)$ & $1(1.8)$ & \\
\hline & Hypothyroidism & $0(0)$ & $1(1.7)$ & & $0(0)$ & $1(1.8)$ & \\
\hline & $\begin{array}{l}\text { Diffuse euthyroid } \\
\text { goiter }\end{array}$ & $1(1.6)$ & $0(0)$ & & $0(0)$ & $0(0)$ & \\
\hline & $\begin{array}{l}\text { Non-toxic nodular } \\
\text { goiter }\end{array}$ & $2(3.1)$ & $1(1.7)$ & & $2(3.6)$ & $1(1.8)$ & \\
\hline & $\begin{array}{l}\text { Primary } \\
\text { hypothyroidism }\end{array}$ & $0(0)$ & $2(3.4)$ & & $0(0)$ & $2(3.6)$ & \\
\hline & Nodular goiter & $1(1.6)$ & $0(0)$ & & $1(1.8)$ & $0(0)$ & \\
\hline & Euthyroid goiter & $1(1.6)$ & $0(0)$ & & $1(1.8)$ & $0(0)$ & \\
\hline & $\begin{array}{l}\text { The number of } \\
\text { patients with at least } \\
\text { one disease in this } \\
\text { group }\end{array}$ & $7(10.9)$ & $5(8.5)$ & 0.765 & $6(10.7)$ & $5(9.1)$ & 1.000 \\
\hline
\end{tabular}

Notes. Data are presented as $\mathrm{n}(\%)$. Frequency analysis was performed using Fisher's exact test. Results are given without correction for multiplicity of comparison. 
Table 6

Concomitant therapy of study participants

\begin{tabular}{|c|c|c|c|c|c|c|c|}
\hline \multirow[t]{2}{*}{ International non-proprietary name } & \multirow{2}{*}{$\begin{array}{l}\text { Trade name of the } \\
\text { drug }\end{array}$} & \multicolumn{3}{|c|}{ ITT-analysis } & \multicolumn{3}{|c|}{ PP-analysis } \\
\hline & & $\begin{array}{l}\text { Divaza } \\
n=64\end{array}$ & $\begin{array}{l}\text { Placebo } \mathrm{n} \\
=59\end{array}$ & $\begin{array}{l}\mathrm{p}- \\
\text { value* }\end{array}$ & $\begin{array}{l}\text { Divaza } \\
\mathrm{n}=56\end{array}$ & $\begin{array}{l}\text { Placebo } \\
\mathrm{n}=55\end{array}$ & $\begin{array}{l}\text { p- } \\
\text { value* }\end{array}$ \\
\hline Total patients who received at least & rug & $\begin{array}{l}57 \\
(89.1)\end{array}$ & $48(81.4)$ & 0.308 & $\begin{array}{l}51 \\
(91.1)\end{array}$ & $46(83.6)$ & 0.78 \\
\hline
\end{tabular}

\section{A. Digestive tract and metabolism}

Preparations used for conditions associated with acidity disorders

$\begin{array}{lllll}\text { omeprazole } & \text { Omez, } & 1(1.6) & 1(1.7) & 1(1.8)\end{array}$

The number of patients who took at least one drug in this group

$\begin{array}{llllll}1(1.6) & 1(1.7) & 1.000 & 1(1.8) & 1(1.8) & 0.267\end{array}$

Diabetes drugs

gliclazide

Diabeton MV

$2(3.1) \quad 0(0)$

2 (3.6) $\quad 0(0)$

metformin hydrochloride

Metformin,

Glucophage,

$7 \quad 0(0)$

(10.9)

$5(8.9) \quad 0(0)$

Siofor 1000

The number of patients who took at least one drug in this group

7

$0(0)$

0.014

$5(8.9)$

$0(0)$

0.057

\section{Mineral supplements}

calcium carbonate + colecalciferol (vit. D3)

Complivit Calcium

$1(1.6) \quad 0(0)$

$1(1.8)$

$0(0)$

The number of patients who took at least one drug in this group

$1(1.6) \quad 0(0)$

1.000

$1(1.8)$

$0(0)$

1.000

\section{B. Blood and hematopoietic system}

Anticoagulants

acetylsalicylic acid

Aspirin Cardio,

14

(21.9)

$11(18.6)$

12

10 (18.2)

Acecardol,

Thrombotic ACC

acetylsalicylic acid + magnesium hydroxide

Cardiomagnet

16

(25.0)

Clopidogrel

Coplavix

Xarelto

rivaroxaban (micronized)

The number of patients who took at least one drug in this group

clopidogrel hydrogen sulfate (form II) +

acetylsalicylic acid

Xarelto

\section{Hemostatic drugs}

etamsylate

Dicinon

The number of patients who took at least one drug in this group

\section{The cardiovascular system}

\section{Antihypertensive drugs}

moxonidine

Moxonidine

The number of patients who took at least one drug in this group

Diuretics

hydrochlorothiazide

Hypothiazide

1 (1.6) $0(0)$

1 (1.8)

$0(0)$

Notes. The analysis was carried out using Fisher's exact test. Results are given without correction for multiplicity of comparison. 


\begin{tabular}{|c|c|c|c|c|c|c|c|}
\hline \multirow[t]{2}{*}{ International non-proprietary name } & \multirow{2}{*}{$\begin{array}{l}\text { Trade name of the } \\
\text { drug }\end{array}$} & \multicolumn{3}{|c|}{ ITT-analysis } & \multicolumn{3}{|c|}{ PP-analysis } \\
\hline & & $\begin{array}{l}\text { Divaza } \\
n=64\end{array}$ & $\begin{array}{l}\text { Placebo } \mathrm{n} \\
=59\end{array}$ & $\begin{array}{l}\text { p- } \\
\text { value* }\end{array}$ & $\begin{array}{l}\text { Divaza } \\
\mathrm{n}=56\end{array}$ & $\begin{array}{l}\text { Placebo } \\
n=55\end{array}$ & $\begin{array}{l}p- \\
\text { value* }\end{array}$ \\
\hline indapamide & $\begin{array}{l}\text { Arifon retard, } \\
\text { Indapamide, } \\
\text { Indapamide retard }\end{array}$ & $\begin{array}{l}11 \\
(17.2)\end{array}$ & $6(10.2)$ & & $9(16.1)$ & $6(10.9)$ & \\
\hline torasemide & Britomar & $0(0)$ & $1(1.7)$ & & $0(0)$ & $1(1.8)$ & \\
\hline \multicolumn{2}{|c|}{ The number of patients who took at least one drug in this group } & $\begin{array}{l}12 \\
(18.8)\end{array}$ & $7(11.9)$ & 0.327 & $\begin{array}{l}10 \\
(17.9)\end{array}$ & $7(12.7)$ & 0.600 \\
\hline \multicolumn{8}{|l|}{ Beta-blockers } \\
\hline atenolol & Atenolol & $1(1.6)$ & $0(0)$ & & $1(1.8)$ & $0(0)$ & \\
\hline atenolol + chlorthalidone & Tenoric & $0(0)$ & $1(1.7)$ & & $0(0)$ & $1(1.8)$ & \\
\hline bisoprolol fumarate & $\begin{array}{l}\text { Bisoprolol, } \\
\text { Concor }\end{array}$ & $\begin{array}{l}15 \\
(23.4)\end{array}$ & $8(13.6)$ & & $\begin{array}{l}15 \\
(26.8)\end{array}$ & $7(12.7)$ & \\
\hline metoprolol succinate & Betalok ZOK & $1(1.6)$ & $2(3.4)$ & & $1(1.8)$ & $2(3.6)$ & \\
\hline metoprolol tartrate & $\begin{array}{l}\text { Metoprolol, } \\
\text { Egilok }\end{array}$ & $3(4.7)$ & $1(1.7)$ & & $3(5.4)$ & $1(1.8)$ & \\
\hline \multicolumn{2}{|c|}{ The number of patients who took at least one drug in this group } & $\begin{array}{l}19 \\
(29.7)\end{array}$ & $12(20.3)$ & 0.300 & $\begin{array}{l}19 \\
(33.9)\end{array}$ & $11(20.0)$ & 0.135 \\
\hline \multicolumn{8}{|l|}{ Calcium channel blockers } \\
\hline amlodipine besilate & Amlodipine & $3(4.7)$ & $1(1.7)$ & & $3(5.4)$ & $1(1.8)$ & \\
\hline nifedipine & Nifecard HL & $1(1.6)$ & $0(0)$ & & $0(0)$ & $0(0)$ & \\
\hline \multicolumn{2}{|c|}{ The number of patients who took at least one drug in this group } & $4(6.3)$ & $1(1.7)$ & 0.367 & $3(5.4)$ & $1(1.8)$ & 0.618 \\
\hline \multicolumn{8}{|l|}{ Drugs affecting the renin-angiotensin system } \\
\hline amlodipine besylate + lisinopril dihydrate & Equator & $1(1.6)$ & $0(0)$ & & $1(1.8)$ & $0(0)$ & \\
\hline valsartan & $\begin{array}{l}\text { Walz, } \\
\text { Valsacor }\end{array}$ & $2(3.1)$ & $1(1.7)$ & & $1(1.8)$ & $1(1.8)$ & \\
\hline valsartan + hydrochlorothiazide & Walz N & $1(1.6)$ & $0(0)$ & & $1(1.8)$ & $0(0)$ & \\
\hline candesartan cilexetil & $\begin{array}{l}\text { Atacand, } \\
\text { Candesartan, } \\
\text { Ordiss }\end{array}$ & $0(0)$ & $3(5.1)$ & & $0(0)$ & $3(5.5)$ & \\
\hline captopril & $\begin{array}{l}\text { Kapoten, } \\
\text { Captopril }\end{array}$ & $0(0)$ & $2(3.4)$ & & $0(0)$ & $2(3.6)$ & \\
\hline lisinopril (in the form of a dihydrate) & Lisinopril & $3(4.7)$ & $2(3.4)$ & & $2(3.6)$ & $2(3.6)$ & \\
\hline losartan potassium & $\begin{array}{l}\text { Lozap, } \\
\text { Losartan, } \\
\text { Lorista }\end{array}$ & $\begin{array}{l}7 \\
(10.9)\end{array}$ & $5(8.5)$ & & $5(8.9)$ & $4(7.3)$ & \\
\hline losartan potassium + hydrochlorothiazide & $\begin{array}{l}\text { Lozap Plus, } \\
\text { Lorista N }\end{array}$ & $1(1.6)$ & $4(6.8)$ & & $1(1.8)$ & $3(5.5)$ & \\
\hline perindopril arginine & Prestarium A & $6(9.4)$ & $3(5.1)$ & & $6(10.7)$ & $3(5.5)$ & \\
\hline perindopril arginine + indapamide & Noliprel A & $1(1.6)$ & $1(1.7)$ & & $1(1.8)$ & $1(1.8)$ & \\
\hline perindopril tert-butylamine salt & Prestarium & $1(1.6)$ & $0(0)$ & & $1(1.8)$ & $0(0)$ & \\
\hline
\end{tabular}




\begin{tabular}{|c|c|c|c|c|c|c|c|}
\hline \multirow[t]{2}{*}{ International non-proprietary name } & \multirow{2}{*}{$\begin{array}{l}\text { Trade name of the } \\
\text { drug }\end{array}$} & \multicolumn{3}{|c|}{ ITT-analysis } & \multicolumn{3}{|c|}{ PP-analysis } \\
\hline & & $\begin{array}{l}\text { Divaza } \\
n=64\end{array}$ & $\begin{array}{l}\text { Placebo } \mathrm{n} \\
=59\end{array}$ & $\begin{array}{l}\text { p- } \\
\text { value* }\end{array}$ & $\begin{array}{l}\text { Divaza } \\
\mathrm{n}=56\end{array}$ & $\begin{array}{l}\text { Placebo } \\
\mathrm{n}=55\end{array}$ & $\begin{array}{l}p- \\
\text { value* }\end{array}$ \\
\hline perindopril erbumin & Perindopril & $0(0)$ & $1(1.7)$ & & $0(0)$ & $1(1.8)$ & \\
\hline perindopril erbumin, semi-finished product granules & Perineva & $2(3.1)$ & $0(0)$ & & $2(3.6)$ & $0(0)$ & \\
\hline ramipril & Ramipril & $0(0)$ & $1(1.7)$ & & $0(0)$ & $0(0)$ & \\
\hline fosinopril sodium & Monopril & $1(1.6)$ & $0(0)$ & & $1(1.8)$ & $0(0)$ & \\
\hline enalapril & Enalapril & $\begin{array}{l}9 \\
(14.1)\end{array}$ & $9(15.3)$ & & $7(12.5)$ & $9(16.4)$ & \\
\hline \multirow[t]{2}{*}{ enalapril maleate } & Renitek, & $6(9.4)$ & $6(10.2)$ & & $6(10.7)$ & $6(10.9)$ & \\
\hline & Enap & & & & & & \\
\hline \multicolumn{2}{|c|}{ The number of patients who took at least one drug in this group } & $\begin{array}{l}41 \\
(64.1)\end{array}$ & $34(57.6)$ & 0.579 & $\begin{array}{l}35 \\
(62.5)\end{array}$ & $32(58.2)$ & 0.700 \\
\hline \multicolumn{8}{|l|}{ Lipid-lowering drugs } \\
\hline atorvastatin calcium & $\begin{array}{l}\text { Atorvastatin, } \\
\text { Atoris }\end{array}$ & $\begin{array}{l}17 \\
(26.6)\end{array}$ & $15(25.4)$ & & $\begin{array}{l}15 \\
(26.8)\end{array}$ & $15(27.3)$ & \\
\hline rosuvastatin calcium & Rosuvastatin & $6(9.4)$ & $4(6.8)$ & & $5(8.9)$ & $4(7.3)$ & \\
\hline simvastatin & Simvastatin & $0(0)$ & $3(5.1)$ & & $0(0)$ & $3(5.5)$ & \\
\hline \multicolumn{2}{|c|}{ The number of patients who took at least one drug in this group } & $\begin{array}{l}23 \\
(35.9)\end{array}$ & $22(37.3)$ & 1.000 & $\begin{array}{l}20 \\
(35.7)\end{array}$ & $22(40.0)$ & 0.698 \\
\hline \multicolumn{8}{|l|}{ G. Genitourinary system and sex hormones } \\
\hline \multicolumn{8}{|l|}{ Drugs for the treatment of urological diseases } \\
\hline tamsulosin hydrochloride & Proflosin & $1(1.6)$ & $0(0)$ & & $1(1.8)$ & $0(0)$ & \\
\hline \multicolumn{2}{|c|}{ The number of patients who took at least one drug in this group } & $1(1.6)$ & $0(0)$ & 1.000 & $1(1.8)$ & $0(0)$ & 1.000 \\
\hline \multicolumn{8}{|c|}{ H. Hormones for systemic use (excluding sex hormones and insulins) } \\
\hline \multicolumn{8}{|l|}{ Drugs for the treatment of thyroid diseases } \\
\hline \multirow[t]{2}{*}{ levothyroxine sodium } & L-Thyroxine, & $2(3.1)$ & $4(6.8)$ & & $2(3.6)$ & $4(7.3)$ & \\
\hline & Eutirox & & & & & & \\
\hline \multicolumn{2}{|c|}{ The number of patients who took at least one drug in this group } & $2(3.1)$ & $4(6.8)$ & 0.425 & $2(3.6)$ & $4(7.3)$ & 0.438 \\
\hline \multicolumn{8}{|l|}{ J. Antimicrobials for systemic use } \\
\hline \multicolumn{8}{|l|}{ Antimicrobials for systemic use } \\
\hline $\begin{array}{l}\text { amoxicillin (sodium salt form) + clavulanic acid } \\
\text { (potassium salt form) }\end{array}$ & Amoxiclav & $1(1.6)$ & $0(0)$ & & $1(1.8)$ & $0(0)$ & \\
\hline doxycycline hydrochloride & Doxycycline & $1(1.6)$ & $0(0)$ & & $1(1.8)$ & $0(0)$ & \\
\hline \multicolumn{2}{|c|}{ The number of patients who took at least one drug in this group } & $2(3.1)$ & $0(0)$ & 0.497 & $2(3.6)$ & $0(0)$ & 0.496 \\
\hline \multicolumn{8}{|l|}{ M. Musculoskeletal system } \\
\hline \multicolumn{8}{|l|}{ Anti-inflammatory and antirheumatic drugs } \\
\hline ibuprofen & Nurofen & $1(1.6)$ & $0(0)$ & & $1(1.8)$ & $0(0)$ & \\
\hline \multicolumn{2}{|c|}{ The number of patients who took at least one drug in this group } & $1(1.6)$ & $0(0)$ & 1.000 & $1(1.8)$ & $0(0)$ & 1.000 \\
\hline \multicolumn{8}{|l|}{ N. Nervous system } \\
\hline \multicolumn{8}{|l|}{ Analgesics } \\
\hline acetylsalicylic acid & Acetylsalicylic acid & $0(0)$ & $1(1.7)$ & & $0(0)$ & $1(1.8)$ & \\
\hline
\end{tabular}

Notes. The analysis was carried out using Fisher's exact test. Results are given without correction for multiplicity of comparison. 


\begin{tabular}{|c|c|c|c|c|c|c|c|}
\hline \multirow[t]{2}{*}{ International non-proprietary name } & \multirow{2}{*}{$\begin{array}{l}\text { Trade name of the } \\
\text { drug }\end{array}$} & \multicolumn{3}{|c|}{ ITT-analysis } & \multicolumn{3}{|c|}{ PP-analysis } \\
\hline & & $\begin{array}{l}\text { Divaza } \\
n=64\end{array}$ & $\begin{array}{l}\text { Placebo } \mathrm{n} \\
=59\end{array}$ & $\begin{array}{l}\text { p- } \\
\text { value* }\end{array}$ & $\begin{array}{l}\text { Divaza } \\
n=56\end{array}$ & $\begin{array}{l}\text { Placebo } \\
n=55\end{array}$ & $\begin{array}{l}\text { p- } \\
\text { value* }\end{array}$ \\
\hline \multicolumn{2}{|c|}{ The number of patients who took at least one drug in this group } & $0(0)$ & $1(1.7)$ & 0.480 & $0(0)$ & $1(1.8)$ & 0.496 \\
\hline \multicolumn{8}{|l|}{ R. Respiratory system } \\
\hline \multicolumn{8}{|l|}{ Drugs for the treatment of diseases of the nose } \\
\hline \multirow[t]{2}{*}{ xylometazoline hydrochloride } & Otrivin, & $1(1.6)$ & $1(1.7)$ & & $1(1.8)$ & $1(1.8)$ & \\
\hline & Snoop & & & & & & \\
\hline oxymetazoline hydrochloride & Nazivin & $1(1.6)$ & $0(0)$ & & $1(1.8)$ & $0(0)$ & \\
\hline \multicolumn{2}{|c|}{ The number of patients who took at least one drug in this group } & $2(3.1)$ & $1(1.7)$ & 1.000 & $2(3.6)$ & $1(1.8)$ & 1.000 \\
\hline \multicolumn{8}{|c|}{ Drugs for the treatment of diseases of the pharynx } \\
\hline 2,4-dichlorobenzyl alcohol + amylmetacresol & Strepsils & $2(3.1)$ & $0(0)$ & & $2(3.6)$ & $0(0)$ & \\
\hline \multicolumn{2}{|c|}{ The number of patients who took at least one drug in this group } & $2(3.1)$ & $0(0)$ & 0.497 & $2(3.6)$ & $0(0)$ & 0.496 \\
\hline \multicolumn{8}{|l|}{ Drugs for the treatment of bronchial asthma } \\
\hline formoterol fumarate dihydrate & Foradil & $0(0)$ & $1(1.7)$ & & $0(0)$ & $1(1.8)$ & \\
\hline \multicolumn{2}{|c|}{ The number of patients who took at least one drug in this group } & $0(0)$ & $1(1.7)$ & 0.480 & $0(0)$ & $1(1.8)$ & 0.496 \\
\hline
\end{tabular}

Table 7

Average levels of the low density and very low density serum LP resistance to oxidation

\begin{tabular}{|c|c|c|c|c|}
\hline \multirow[t]{2}{*}{ Index } & \multicolumn{2}{|c|}{ ITT-analysis $(n=122) *$} & \multicolumn{2}{|c|}{ PP-analysis $(n=111)$} \\
\hline & $\begin{array}{l}\text { Divaza }(n= \\
63)\end{array}$ & $\begin{array}{l}\text { Placebo }(n= \\
59)\end{array}$ & $\begin{array}{l}\text { Divaza }(\mathrm{n}= \\
56)\end{array}$ & $\begin{array}{l}\text { Placebo }(n= \\
55)\end{array}$ \\
\hline \multirow{2}{*}{$\begin{array}{l}\text { The low density and very low density serum LP resistance to oxidation, baseline, } \\
\mathrm{mV} \\
\text { Mean } \pm \mathrm{SD}\end{array}$} & $42.4 \pm 13.1$ & $42.9 \pm 11.2$ & $40.8 \pm 10.8$ & $42.2 \pm 10.9$ \\
\hline & \multicolumn{4}{|c|}{ Mean \pm SD } \\
\hline \multicolumn{5}{|l|}{ Median } \\
\hline \multirow{2}{*}{$\begin{array}{l}\text { The low density and very low density serum LP resistance to oxidation, after } 12 \\
\text { weeks therapy, } \mathrm{mV}\end{array}$} & $55.6 \pm 12.5$ & $49.4 \pm 14.3$ & $55.6 \pm 12.5$ & $49.3 \pm 14.4$ \\
\hline & \multicolumn{4}{|c|}{ Mean \pm SD } \\
\hline \multicolumn{5}{|l|}{ Median } \\
\hline$\Delta$ (within groups between visits), $\mathrm{mV}$ & $14.8 \pm 14.7$ & $6.4 \pm 16.9$ & $14.8 \pm 14.7$ & $6.9 \pm 16.7$ \\
\hline \multicolumn{5}{|l|}{ Mean \pm SD } \\
\hline$\Delta$ (between the deltas of Divaza and placebo groups), $\mathrm{mV}$ & \multirow{2}{*}{\multicolumn{2}{|c|}{$8.4 \pm 15.9$}} & \multirow{2}{*}{\multicolumn{2}{|c|}{$7.9 \pm 15.7$}} \\
\hline Mean \pm SD & & & & \\
\hline Statistics** & \multicolumn{2}{|c|}{$t=2.75 ; p=0.007$} & \multicolumn{2}{|c|}{$t=2.6 ; p=0.0107$} \\
\hline
\end{tabular}


Table 8

Percentage of patients with cognitive improvement

\begin{tabular}{|c|c|c|c|c|}
\hline Sample & ITT-analysis $(n=$ & & PP-analysis $(\mathrm{n}=$ & \\
\hline Group & Divaza $(n=56)$ & Placebo $(n=57)$ & Divaza $(n=56)$ & Placebo $(n=57)$ \\
\hline Patient number (percentage) & $56(100)$ & $51(89.5)$ & $56(100)$ & $49(89.1)$ \\
\hline Statistics** & $p=0.0272$ & & $p=0.0128$ & \\
\hline
\end{tabular}

Table 9

AEs in two groups

\begin{tabular}{|c|c|c|c|}
\hline \multirow[t]{2}{*}{ System-organ-class/Description of AE } & \multicolumn{2}{|l|}{ Group } & \multirow[t]{2}{*}{ p-value } \\
\hline & Divaza $n=64$ & Placebo $n=59$ & \\
\hline Total patients with at least one AE & $5(7.8)$ & $3(5.1)$ & 0.719 \\
\hline Total AEs & 5 & 3 & \\
\hline Gastrointestinal disorders & $1(1.6)$ & $0(0)$ & 1.000 \\
\hline Number of patients with at least one AE & $1(1.6)$ & $0(0)$ & \\
\hline \multicolumn{4}{|l|}{ Pain when swallowing } \\
\hline Infections and invasions & $2(3.1)$ & $1(1.7)$ & 1.000 \\
\hline Number of patients with at least one $\mathrm{AE}$ & $1(1.6)$ & $0(0)$ & \\
\hline Acute nasopharyngitis & $1(1.6)$ & $1(1.7)$ & \\
\hline \multicolumn{4}{|l|}{ Acute respiratory tract infection } \\
\hline Laboratory and instrumental data & $0(0)$ & $1(1.7)$ & 0.476 \\
\hline Number of patients with at least one $\mathrm{AE}$ & $0(0)$ & $1(1.7)$ & \\
\hline \multicolumn{4}{|l|}{ Increased blood pressure } \\
\hline Respiratory, chest and mediastinal disorders & $0(0)$ & $1(1.7)$ & 0.476 \\
\hline Number of patients with at least one AE & $0(0)$ & $1(1.7)$ & \\
\hline \multicolumn{4}{|l|}{ Nose bleed } \\
\hline Nervous system disorders & $1(1.6)$ & $0(0)$ & 1.000 \\
\hline Number of patients with at least one $A E$ & $1(1.6)$ & $0(0)$ & \\
\hline \multicolumn{4}{|l|}{ Headache } \\
\hline Injury, intoxication and complications of procedures & $1(1.6)$ & $0(0)$ & 1.000 \\
\hline Number of patients with at least one AE & $1(1.6)$ & $0(0)$ & \\
\hline Tick bite & & & \\
\hline
\end{tabular}

\section{Figures}




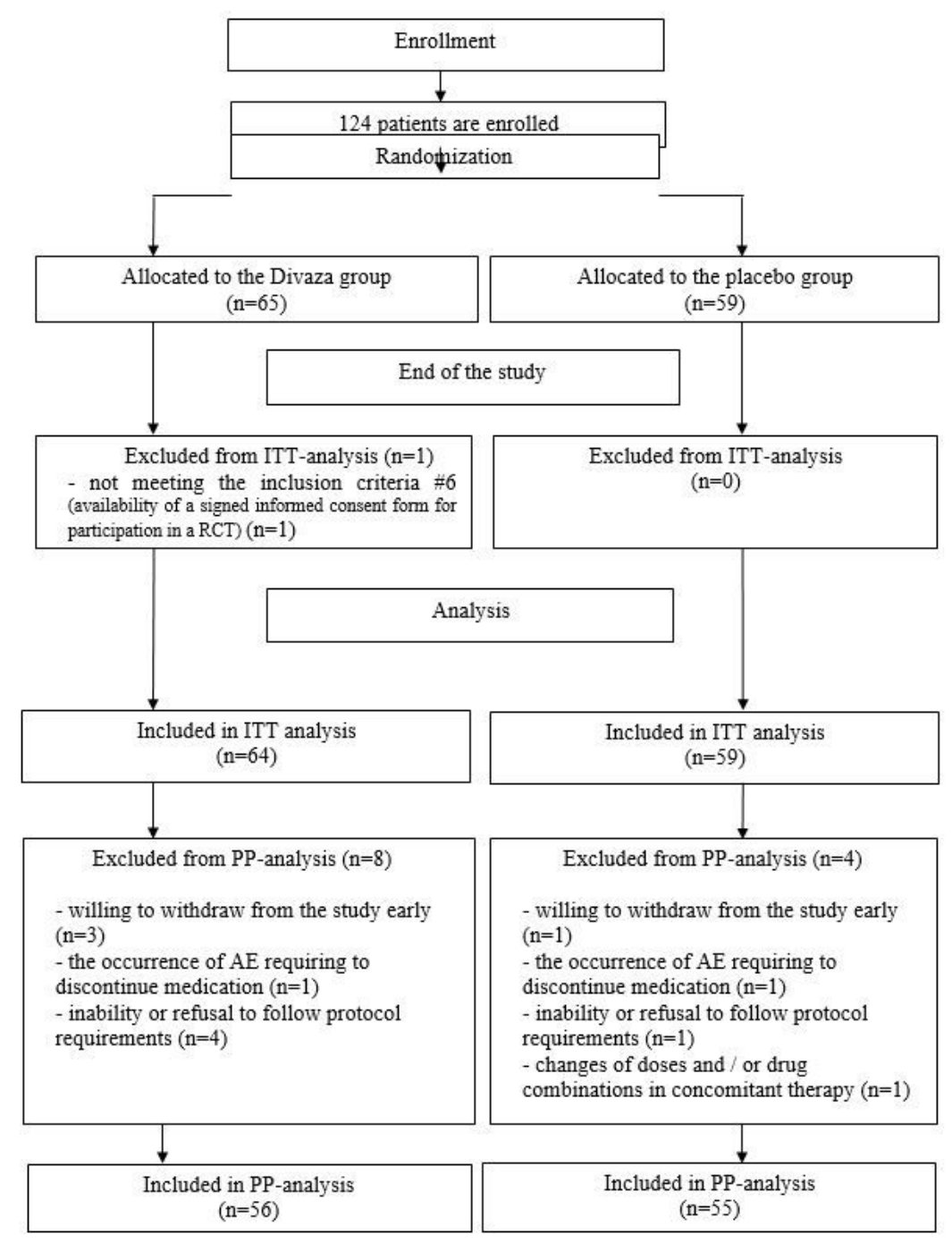

Figure 1

Participant flow in the clinical trial

\section{Supplementary Files}

This is a list of supplementary files associated with this preprint. Click to download.

- CONSORT2010Checklist.doc 